Integrated assessment, valuation and mapping of ecosystem services and dis-services from upland land use in Wales

Hardaker, Ashley; Pagella, Tim; Rayment, Mark

\title{
Ecosystem Services
}

DOI:

10.1016/j.ecoser.2020.101098

Published: 01/06/2020

Peer reviewed version

Cyswllt i'r cyhoeddiad / Link to publication

Dyfyniad o'r fersiwn a gyhoeddwyd / Citation for published version (APA):

Hardaker, A., Pagella, T., \& Rayment, M. (2020). Integrated assessment, valuation and mapping of ecosystem services and dis-services from upland land use in Wales. Ecosystem Services, 43, [101098]. https://doi.org/10.1016/j.ecoser.2020.101098

\footnotetext{
Hawliau Cyffredinol / General rights

Copyright and moral rights for the publications made accessible in the public portal are retained by the authors and/or other copyright owners and it is a condition of accessing publications that users recognise and abide by the legal requirements associated with these rights.

- Users may download and print one copy of any publication from the public portal for the purpose of private study or research.

- You may not further distribute the material or use it for any profit-making activity or commercial gain

- You may freely distribute the URL identifying the publication in the public portal?
}

Take down policy

If you believe that this document breaches copyright please contact us providing details, and we will remove access to the work immediately and investigate your claim. 
1 Integrated assessment, valuation and mapping of ecosystem services 2 and dis-services from upland land use in Wales. 3

4 Ashley Hardakera, Tim Pagellaa and Mark Rayment ${ }^{a}$

5

6 aSchool of Natural Sciences, Bangor University, Bangor, Wales, LL57 2UW

7

8 Email of Ashley Hardaker (corresponding author): afpb0d@bangor.ac.uk

9 Email of Tim Pagella: t.pagella@bangor.ac.uk

10 Email of Mark Rayment: m.rayment@bangor.ac.uk 


\title{
11 Integrated assessment, valuation and mapping of ecosystem services and dis-services from upland land use in Wales
}

13

14

15

16

17

18

19

\begin{abstract}
Upland land use in Wales has high potential value in relation to the delivery of ecosystem services which is currently uncaptured. In this study we assessed the ecosystem services and dis-services generated by the two dominant land uses (forestry and agricultural) in the uplands of Wales in qualitative and monetary units. We also mapped the distribution of ecosystem services and dis-services across the two dominant land uses. Our results provide an initial baseline estimate of the supply and economic value of ecosystem services and dis-services from upland forestry and agricultural land use in Wales. The qualitative assessment showed the highest levels of ecosystem service supply were derived from forestry land use and the highest levels of ecosystem dis-services were derived from agricultural land use. The economic value of ecosystem service benefits from upland land use in Wales is $£ 1,472.25$ million year $^{-1}$ and the total costs of ecosystem dis-services are $£ 101.54$ million year ${ }^{-1}$ using 2018 values. When an economic weighting is applied the per hectare economic value of ecosystem service benefits from agriculture at $£ 1,434.02 \mathrm{ha}^{-1}$ year ${ }^{-1}$ is higher than that of forestry at $£ 1,261.09 \mathrm{ha}^{-1}$ year ${ }^{-1}$ and the per hectare costs of ecosystem dis-services from agriculture at $£ 96.10$ ha $^{-1}$ year $^{-1}$ was marginally lower than that of forestry at $£ 98.58$ ha $^{-1}$ year ${ }^{-1}$. Overall our results highlight an imbalance in the current delivery of ecosystem services from upland land use in Wales with the majority of benefits coming in the form of private benefits through provisioning services. By using systematic qualitative and economic assessment tools this study has highlighted critical data gaps and provides a basis for rebalancing ecosystem service delivery and increasing levels of public benefits through expansion of tree cover within the Welsh uplands. Our mapping highlights where land use adaption and transformation may be approached to address the imbalance in ecosystem service supply.
\end{abstract}

Keywords: Forestry, Agriculture, Ecosystem Service Assessment, Qualitative Assessment, Economic Valuation

\section{Introduction}

Land use in the Welsh uplands is dominated by low-intensity sheep and cattle grazing with smaller amounts of high-volume, low quality softwood timber production interspersed with areas of unproductive amenity woodland (Armstrong, 2016; National Assembly for Wales, 2013). Upland systems are relatively slow to react to change, however, recent political activity in the UK associated with withdrawal from the EU has put the future direction of upland land use into question (Hubbard et al., 2018). A decline in upland agriculture could bring about a significant shift in the balance of ecosystem services delivered from these systems. Given the increased economic vulnerability of agriculture and to a lesser degree forestry within upland systems (Hardaker, 2018) it is important that we capture their broader ecosystem service values robustly to inform future land use priorities.

Upland land use systems in the United Kingdom (UK) have high potential value in relation to the delivery of ecosystem services (ES) (Bonn et al., 2009; Evans, 2009; Hubacek et al., 2009; Reed et al., 2009). As the management of semi-natural systems increase so does the potential to generate ecosystem dis-services (EDS) (MEA, 2005; Mouchet et al., 2017; Rodríguez et al., 2006). At present broad scale 
systemic assessment and valuation of ES from upland systems has been minimal; most do not use the uplands as a specific reference frame and are based on a mix of habitat types rather than land use (UKNEA, 2011). What studies exist that evaluate land use and ES have focused a) predominantly on forest systems and b) principally on a single or a few services; notably timber production and its relation to carbon sequestration (Bateman and Lovett, 2000; Brainard et al., 2009), recreational use (Scarpa, 2003; Sen et al., 2011) and hydrological services (Willis, 2002). Other authors have made attempts at estimating the total value of the UK forest resource (Eftec, 2010; Europe Economics, 2017; Saraev et al., 2017; Willis et al., 2003). Notably, very little attention has been given to valuation of ES from agricultural systems, which is the dominant land use in the UK uplands. The two studies that exist also fail to distinguish between different forms of upland and lowland agriculture (Fezzi et al., 2014; Pretty et al., 2000). Very few studies in the UK have captured ecosystem dis-services associated with current and alternative land use strategies.

The Welsh uplands offer a particularly interesting case study as the upland area accounts for a significant proportion of the total land area. With specific reference to the Welsh Uplands there exists a critical knowledge gap around the assessment and valuation of ES considering the potential importance of upland areas for ES delivery and the growing demands on these systems.

\subsection{Objective and aims}

The objective of this study is to address the critical knowledge gap surrounding the supply of ES and EDS and the economic value (EV) of ES benefits and EDS costs from upland land use, using the Welsh uplands as a case study. The principal aims of this study were to:

\section{Materials and methods}

\subsection{The study area}

Uplands are potentially difficult to define (Mansfield, 2011). We defined the Welsh uplands as the Severely Disadvantaged Area (SDA) under the Less Favoured Area (LFA) designation (EC Directive 75/268). In this study any reference to agriculture refers to all agricultural land use (livestock grazing and arable) undertaken in the SDA and forestry refers to all forests and woodland both productive (primarily plantation softwoods) and non-productive (predominantly broadleaf or mixed woodland, retained 
primarily for amenity or for conservation value). The predominant land use in the Welsh uplands is agriculture, covering 846,963ha (Natural Resources Wales, 2018) and is a combination of improved and semi-improved pasture and arable at lower altitudes (covering 56\% of the agricultural area) and unimproved grassland and rough grazing (including marshy grassland, ffridd, heathland, mire, and tall herb and fern) on the hills and steeper slopes (covering the remaining $44 \%$ of the agricultural area) - see figure 1. The total area of forestry land use in the Welsh uplands extends to 204,337ha (Natural Resources Wales, 2018). The main forest cover types are coniferous, broadleaf and mixed, covering $75 \%, 23 \%$ and $2 \%$ of the total afforested area respectively - see figure 1.

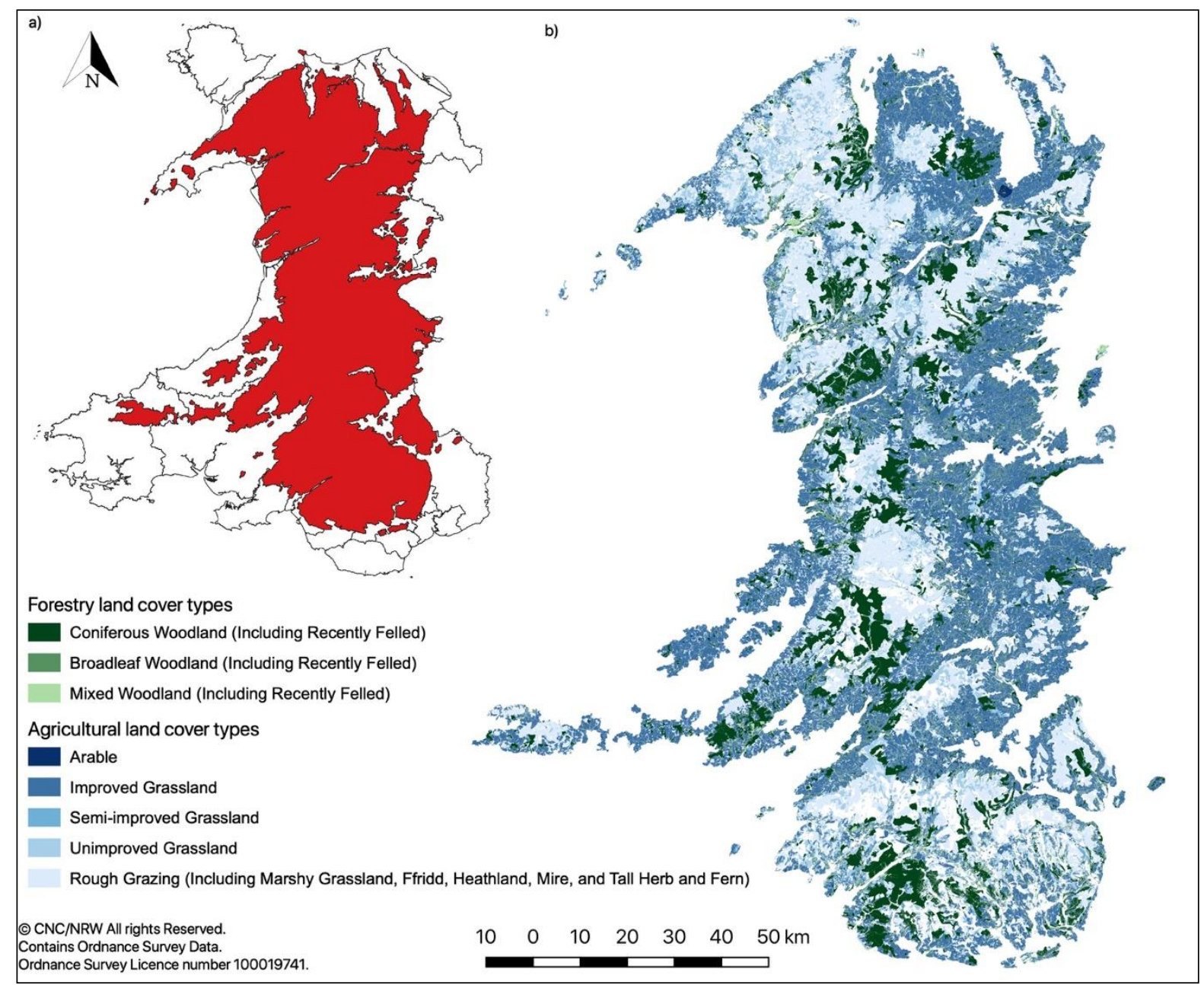

Figure 1: a) Extent of the Severely Disadvantaged Area (SDA) in Wales and b) distribution of forestry and agricultural land use and land cover in SDA

\subsection{Ecosystem services framework}

In this study ES were defined as as the flows of services and goods from ecosystems that provide benefits to humans (de Groot et al., 2010; Haines-Young and Potschin, 2010). As a development of earlier work generally and in Wales more specifically (Saraev et al., 2017) we also considered EDS. EDS are the result of functions and processes of ecosystems that lead to negative impacts on humans (Blanco et al., 
2019; Dunn, 2010; Schaubroeck, 2017; Shackleton et al., 2016). In this study EDS are defined as the flows

100 of dis-services that provide costs to humans. By including EDS in our analysis, we present a more balanced

101 view of the net benefits of upland land use in Wales. To classify ES and EDS we use the Common

Haines-Young and Potschin, 2017).

\subsection{Integrated qualitative and economic valuation approach}

Due to limited existing data for the Welsh uplands we took an integrated qualitative scored and quantitative economic valuation approach, assessing the supply of ES and EDS and net ecosystem services (NES) supply first in qualitative scored terms and then estimating economic values of the benefits and costs where data permitted. We included EDS and NES supply as although ES supply shows the positive importance of upland land use these values alone provides an incomplete basis for assessing the relative

111 benefits of upland land in Wales as it neglects the externalities associated with different land uses

112 (Wegner and Pascual, 2011). The qualitative assessment highlights knowledge gaps and informs the 113 scope of the economic valuation.

Table 1: Ecosystem services and dis-services included in each stage of the integrated assessment (based on all land

115 cover captured in figure 1 and for the subset of ecosystem services and dis-services where supply can be inferred

116 from land cover data)

\begin{tabular}{|c|c|c|c|c|c|c|}
\hline \multirow[t]{2}{*}{ Ecosystem services and dis-service } & \multicolumn{2}{|c|}{$\begin{array}{l}\text { Stage 1: Qualitative } \\
\text { assessment of capacity to } \\
\text { deliver ES and EDS and } \\
\text { potential level of supply } \\
\text { (Section 2.3.1.1 and 2.3.1.2) }\end{array}$} & \multicolumn{2}{|c|}{$\begin{array}{l}\text { Stage 2: Qualitative spatial } \\
\text { assessment of ES and EDS } \\
\text { supply (Section 2.3.1.3) }\end{array}$} & \multicolumn{2}{|c|}{$\begin{array}{c}\text { Stage 3: Quantitative } \\
\text { assessment of assessment } \\
\text { and mapping of economic } \\
\text { values (Section 2.3.2) }\end{array}$} \\
\hline & Forestry & Agriculture & Forestry & Agriculture & Forestry & Agriculture \\
\hline \multicolumn{7}{|l|}{ Provisioning services } \\
\hline Livestock production & - & $\checkmark$ & - & $\checkmark$ & - & $\checkmark$ \\
\hline Arable crops & - & $\checkmark$ & - & $\checkmark$ & - & $\checkmark$ \\
\hline Timber production & $\checkmark$ & - & $\checkmark$ & - & $\checkmark$ & - \\
\hline Water supply for consumptive use & $\checkmark$ & $\checkmark$ & $\checkmark$ & $\checkmark$ & $\checkmark$ & $\checkmark$ \\
\hline \multicolumn{7}{|l|}{ Provisioning dis-services } \\
\hline Potable water quality reduction & $\checkmark$ & $\checkmark$ & $\checkmark$ & $\checkmark$ & $\checkmark$ & $\checkmark$ \\
\hline \multicolumn{7}{|l|}{ Regulation and maintenance services } \\
\hline Carbon sequestration & $\checkmark$ & $\checkmark$ & $\checkmark$ & $\checkmark$ & $\checkmark$ & $\checkmark$ \\
\hline Livestock shelter and shade & $\checkmark$ & - & $x$ & $x$ & $x$ & $x$ \\
\hline Local flood risk mitigation & $\checkmark$ & $\checkmark$ & $\checkmark$ & $x$ & $\checkmark$ & $x$ \\
\hline Potable water quality maintenance & $\checkmark$ & $x$ & $\checkmark$ & $x$ & $x$ & $x$ \\
\hline \multicolumn{7}{|l|}{ Regulation and maintenance dis-services } \\
\hline Elevated localised flood risk & $\checkmark$ & $\checkmark$ & $\checkmark$ & $\checkmark$ & $x$ & $x$ \\
\hline GHG emissions & $\checkmark$ & $\checkmark$ & $\checkmark$ & $\checkmark$ & $\checkmark$ & $\checkmark$ \\
\hline \multicolumn{7}{|l|}{ Cultural services } \\
\hline Employment & $\checkmark$ & $\checkmark$ & $\checkmark$ & $\checkmark$ & $\checkmark$ & $\checkmark$ \\
\hline Landscape amenity & $\checkmark$ & $\checkmark$ & $x$ & $x$ & $x$ & $x$ \\
\hline Recreation & $\checkmark$ & $\checkmark$ & $\checkmark$ & $\checkmark$ & $x$ & $x$ \\
\hline
\end{tabular}




\subsubsection{Qualitative assessment}

118 The qualitative element of the integrated assessment consisted of a) an initial literature review

119 combined with construction of potential ES and EDS supply level matrices and b) spatially explicit 120 assessment of the supply of ES and EDS from the two different upland land uses.

121

\subsubsection{Potential ecosystem service and dis-service supply level matrices}

123 We conducted a literature review to determine which ES and EDS the two dominant land uses

124 and their associated constituent land cover types in the Welsh uplands have the capacity to deliver. We

125 used the Terrestrial Phase 1 Habitat Survey (Natural Resources Wales, 2018) spatial data to delineate

126 land cover types as proxies for ecosystem structures and functions that support ES and EDS delivery and

127 thus capacity to supply ecosystem services. More specifically we used the Level 2 Phase 1 habitat codes

128 (e.g. coniferous woodland and improved grassland) to define our land cover types. These land cover types

129 were associated with their respective land use (e.g. coniferous woodland to forestry and improved

130 grassland to agriculture). The ES and EDS within the CICES classification for which it was determined there

131 existed evidence (that could be inferred from land cover data) of capacity to be delivered and included

132 in the qualitative assessment are shown in Table 1. The CICES classification has 88 ES class types, the

133 literature review identified 14 ES and EDS with capacity to be delivered by upland land use in Wales - for

134 a full overview of the literature review see Supplementary Material Table 1.

135 We used an adapted version of the matrix approach (Burkhard et al., 2012, 2010) to quantify the

136 level of potential ES, EDS and NES suppluand links this to varying land cover types. The matrix contains

137 the 14 ES and EDS (as identified in Section 2.3.1.1) on the $x$ - axis and the land use and land cover types

138 on the $\mathrm{y}$ - axis. At the intersections, we assessed (based on evidence from the literature review) the

139 different land cover types' level of supply of individual ES on a scale consisting of: $0=$ no supply, $1=$ very

140 low supply, 2 = low supply, $3=$ moderate supply, $4=$ high supply and $5=$ very high supply. For EDS, the

141 same scale was used but with negative values. Our assignment of supply level scores was based on

142 evidence derived from the literature review with uncertainty levels dictated by cell colours. Our

143 attributed scores are relative values and should only be interpreted in relation to the subset of land cover

144 types included in this assessment. Where the ES or EDS are discrete and can only manifest one way a

145 single supply score is given. Where the ES and EDS are an analogue of one another (e.g. flood risk

146 deviation) and can manifest in either a positive or negative way, a range of scores from negative to 147 positive was given. 


\subsubsection{Spatial assessment of actual ecosystem service and dis-service supply}

We used GIS to map the actual level of ES and EDS supply. Actual supply of ES is the combination of potential supply and the associated human demand (Fisher et al., 2009, 2008; Goldenberg et al., 2017; Verhagen et al., 2015). For some ES and EDS in this study the associated demand is spatially dependent (e.g. timber production and potable water quality reduction). Where this is the case, we used a range of spatial proxies for demand to determine where actual supply is realised (see Supplementary Material Table 2). The ES and EDS included in the spatial assessment are shown in Table 1, due to constraints on spatial data to quantify demand only 12 of the 14 ES and EDS identified in the literature review were included in the qualitative spatial assessment. We used the Terrestrial Phase 1 Habitat Survey (Natural Resources Wales, 2018) spatial shapefile data to delineate the land cover parcels within the SDA, each polygon within the dataset represents an individual parcel of land within the SDA. To define land cover parcels within the SDA where demand for ES and EDS was present we performed spatial queries using GIS to tag land cover parcels based on their spatial relationship (in this case where they overlap) with the spatial proxies for ES and EDS demand (e.g. shapefiles charting acid sensitive catchments as a proxy for

163 potable water quality reduction from forestry land use). Where demand for a particular ES or EDS exists 164 in a land cover parcel, we tagged it with a yes and we assigned it the corresponding ES and EDS supply 165 level score from the potential supply matrix. Where no demand existed for each ES or EDS in a land cover 166 parcel, we tagged it with a no and assigned a zero score for actual supply. We summed the individual ES 167 and EDS scores in each land cover parcel to provide a score for ES, EDS and Net ES (NES) Supply (ES score minus EDS score). We created GIS maps comparing these scores across the two land uses using the following scale to visualise the level of ES, and NES supply: $0=$ no supply, 1 to $6=$ very low supply, 7 to 12

$170=$ low supply, 13 to $18=$ moderate supply, 19 to $24=$ high supply and =>25 = very high supply. For EDS 171 the same scale was used but with negative values.

\subsubsection{Quantitative assessment}

174 The quantitative element of the integrated assessment consisted of a) economic valuation of ES 175 benefits, EDS costs and NES benefits and $b$ ) mapping of the EV of ES benefits, EDS costs and NES benefits 176 from the two different upland land uses.

\subsubsection{Economic valuation}

The economic valuation involved estimating the EV of ES benefits and EDS costs and also the EV

180 of NES benefits (ES benefits minus EDS costs) which is analogous to the overall positive welfare changes 181 from upland land use in Wales. The ES and EDS included in the economic valuation are outlined in table 1821 , due to data constraints only 9 of the 12 ES and EDS included in the qualitative spatial assessment were 
183 included in the economic valuation. In this study we followed a benefit transfer approach (Ferrini et al., 184 2015; Johnston and Wainger, 2015) and used country specific biophysical data and economic unit values 185 to undertake the valuation. In this study we focussed on monetary valuation of direct and indirect use 186 values as defined under the Total Economic Value (TEV) Framework; where the economic value of ES 187 benefits includes all elements of utility provided by the direct and indirect use of ES using monetary 188 accounting units (Freeman, 2003; Pearce and Turner, 1990; Pearce, 1993). Non-use values were 189 disregarded due to the lack of available data to infer their supply from land cover data. Therefore, we

190 refer to the results of our economic valuation as the "economic value" not the "total economic value" as 191 we do not include non-use values such as existence value or bequest value. We also include the EV of dis192 utility provided EDS costs. Our EV estimates across forestry and agricultural land use are based the total 193 area of actual ES and EDS supply (e.g. hectares of agricultural land cover types tagged with yes supplying 194 arable crops) taken from the qualitative spatial assessment, combined with the corresponding biophysical 195 quantities (e.g. tonnes arable crops $\mathrm{ha}^{-1}$ ) and economic unit values (e.g. $f$ tonne ${ }^{-1}$ arable crops). In this 196 study the EV of each ES and EDS supplied by the two land uses was calculated as:

$197 E V_{i}=s_{i} p_{i}$

199 where $S_{i}$ is the biophysical supply of $\mathrm{ES}_{i}$ or $\mathrm{EDS}_{i}$, e.g. tonnes of $\mathrm{CO}_{2}$ and $p_{i}$ is the market or shadow price 200 of $\mathrm{ES}_{i}$ or EDS ${ }_{i}$, e.g. ftonne ${ }^{-1} \mathrm{CO}_{2}$ (Howarth and Farber, 2002). The total aggregated EV of ES and EDS from 201 each land use was calculated as:

$E V_{\text {for } / a g}=\sum_{i=1}^{n} s_{i} p_{i}$

where $E V_{\text {for } / g \text { g }}$ is the sum of the values of all ES benefits and EDS costs that each land use (forestry/agricultural) generates. The total aggregated EV of ES and EDS from upland land use as whole (forestry and agricultural land use combined) was calculated as:

$E V_{\text {tot }}=E V_{\text {for }}+E V_{a g}$

209 where $E V_{\text {tot }}$ is the aggregated total for both land uses combined, $E V_{\text {for }}$ is the aggregated total for forestry 210 land use and $E V_{a g}$ is the aggregated total for agricultural land use. We also estimated the EV ha-1 of ES 211 benefits and EDS costs across the constituent land cover types of each land use for use in the mapping of 212 economic values. In this study the per hectare EV of each ES and EDS supplied by the two land uses was 213 calculated as: 
where $s_{i} h a^{-1}$ is the biophysical supply of ES or EDS $_{i}$ from a hectare of each constituent land cover

217 type, e.g. $\mathrm{m}^{3}$ timber ha- ${ }^{-1}$ and $p_{i}$ is the market or shadow price of $\mathrm{ES}_{i}$ or $\mathrm{EDS}_{i}$, e.g. $\mathrm{fm}^{3}$ timber (Howarth 218 and Farber, 2002). In addition to the aggregated EV across the two land uses combined, we disaggregated 219 the aggregated EV into different bundles for each beneficiary group in order to identify the distribution of across the spectrum of beneficiary groups. We disaggregated the aggregated EV by the population of the relevant beneficiary groups using population data as at 2011 taken from Population Reference Bureau (2011); Reis et al. (2017).

\subsection{Economic valuation methods and calculation procedures}

For the economic valuation we used pricing techniques; specifically, a combination of market price observations and non-market pricing methods (Howarth and Farber, 2002). The market price method was used to estimate the value of ES benefits (livestock production, arable crops, timber production, water supply for consumptive use and employment) that are tradeable on markets that are well functioning and individual unit market prices are well defined (Dasgupta, 2008; Bateman et al., 2014). The market price method assumes that prevailing market prices are a reflection of the minimum willingness to pay (WTP) for the ecosystem services that are tradeable on competitive markets and provide a conservative lower bound estimate of WTP (Howarth and Farber, 2002). For the ES benefits and EDS costs without observable or specific market prices, we used non-market pricing methods to estimate shadow prices (Dasgupta, 2008; Flores, 2003; Howarth and Farber, 2002). We used the replacement cost (Bateman et al., 2014; Dixon et al., 1997) for carbon sequestration and local flood risk reduction and averting behaviour methods (Dickie, 2003; Flores, 2003; Bateman et al., 2014) for GHG emissions and potable water quality reduction. These methods assume that the costs of mitigating damages or replacing ecosystem functions are equivalent to the minimum WTP for ES benefits and willingness to avoid (WTA) EDS costs. For a full overview of the ES and EDS specific calculation procedures

240 (including the specific data sources) used in the economic valuation see Supplementary Material Table 3 241 and Section 5. All EV estimates are based on 2018 figures and represent the annual EV at a single point

242 in time which ceteris paribus would be supplied each year ad infinitum.

\section{$244 \quad$ 2.3.2.1.2 Uncertainty analysis}

245 We undertook an uncertainty analysis to detect the influence of uncertainty in the market and 246 calculated shadow prices would have on the economic values. We used the Monte Carlo simulation 247 method (Metropolis and Ulam, 1949) to determine the combined effects of the input data uncertainties 
based on the distribution functions of the input data parameters. Using the Monte Carlo simulation method, we employed a uniform random function using a range of $\pm 20 \%$ for market and calculated shadow prices and ran this over 10,000 simulations. A uniform random function was chosen as the best probability distribution for the input data as the input variable variation is unknown and and only its minimum and maximum values can be estimated (Sivia, 1996).

\subsubsection{Mapping of economic values}

We used the economic values ha-1 of ES benefits and EDS costs (as described in section 2.3.2.1) and GIS to create a set of maps comparing the economic values across the two land uses (agricultural and

257 forestry land use). We used the same 9 ES and EDS included in the economic values as shown in Table 1.

258 Again we used the Terrestrial Phase 1 Habitat Survey (Natural Resources Wales, 2018) spatial shapefile 259 data to delineate the land cover parcels within the SDA, each polygon within the dataset represents an 260 individual parcel of land within the SDA. We followed the same procedure as described in Section 2.3.1.2 to define land cover parcels within the SDA where demand for ES and EDS was present. Where demand for a particular ES or EDS exists in a land cover parcel and was tagged with a yes and we assigned it the corresponding economic values ha ${ }^{-1}$ for each ES benefit and EDS cost for each land cover type derived from the economic valuation. Where no demand existed for each ES or EDS in a land cover parcel, we tagged it with a no and assigned a zero value. We summed the individual ES and EDS values in each land cover parcel to provide an EV for ES benefits, EDS costs and Net ES (NES) benefits.

\section{3. Results}

\subsection{Qualitative assessment of ecosystem service and dis-service supply}

\section{$270 \quad 3.1 .1$ Potential ecosystem service and dis-service supply matrix}

Based on the subset of 14 ES and EDS, the level of potential ES supply is generally higher for

272 forestry land use than for agriculture with the potential level of ES supply from coniferous, broadleaf and 273 mixed woodland well exceeding that of most agricultural land cover types - as shown in the matrix in

274 Figure 2. The level of potential EDS supply is higher from agricultural land use than forestry with all 275 agricultural land cover types potentially supplying a level of EDS in excess of all forestry land cover types 276 - as shown in the matrix in Figure 2. Even though potential ES supply is relatively high for agriculture 277 (particularly mire with a score of 20), the high levels of EDS (particularly improved grassland with a score 278 of -13) heavily affects the potential NES supply from agricultural land use. Consequently, the level of 279 potential NES supply is significantly higher for forestry than agriculture. However, due to some categories 280 of ES supplied from forestry also potentially manifesting as EDS (potable water quality) there is greater variability in the level of potential NES supply, indicating that forestry land use may perform better in 
282 some areas than in others. Overall the land cover type with the highest potential NES supply is broadleaf 283 woodland. 


\begin{tabular}{|c|c|c|c|c|c|c|c|c|c|c|c|c|c|c|c|c|}
\hline \multirow[b]{3}{*}{$\begin{array}{l}\text { Upland } \\
\text { land use }\end{array}$} & \multirow[b]{3}{*}{$\begin{array}{l}\text { Associated land } \\
\text { cover }\end{array}$} & \multicolumn{12}{|c|}{ Type of ecosystem services and dis-services (CICES Classification) } & & & \\
\hline & & \multicolumn{5}{|c|}{ Provisioning } & \multicolumn{4}{|c|}{ Regulation and maintenance } & \multicolumn{3}{|c|}{ Cultural } & & & \\
\hline & & 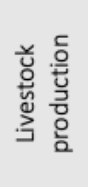 & $\begin{array}{l}\frac{\text { O }}{0} \\
\frac{0}{0} \\
\frac{0}{0} \\
\frac{0}{4}\end{array}$ & 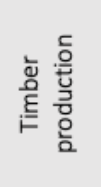 & 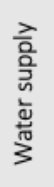 & 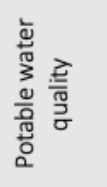 & 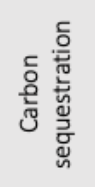 & 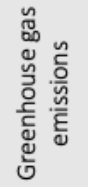 & 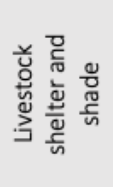 & 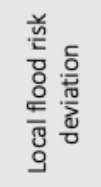 & 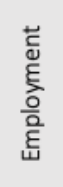 & 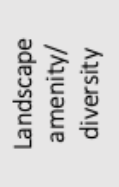 & 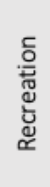 & $\begin{array}{c}\text { Total } \\
\text { potential } \\
\text { ES supply } \\
\text { score }^{2}\end{array}$ & $\begin{array}{c}\text { Total } \\
\text { potential } \\
\text { EDS } \\
\text { supply } \\
\text { score }^{2}\end{array}$ & $\begin{array}{c}\text { Total net } \\
\text { potential } \\
\text { ES supply } \\
\text { score }^{2}\end{array}$ \\
\hline \multirow{6}{*}{ 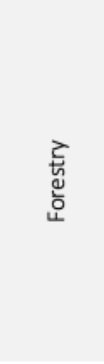 } & Conifer & 0 & 0 & 5 & 2 & -2 to 1 & 5 & -4 & 3 & 3 & 3 & 1 & 3 & 23 & -6 to -4 & 19 to 23 \\
\hline & $\begin{array}{l}\text { Recently felled } \\
\text { conifer }\end{array}$ & 0 & 0 & 0 & 3 & -3 to 0 & 1 & 0 & 0 & -2 & 3 & 0 & 1 & 8 & -5 to -2 & 3 to 8 \\
\hline & Broadleaf & 0 & 0 & 3 & 2 & 4 & 4 & -3 & 3 & 2 & 2 & 4 & 4 & 28 & -3 & 25 \\
\hline & $\begin{array}{l}\text { Recently felled } \\
\text { broadleaf }\end{array}$ & 0 & 0 & 0 & 3 & -3 to 0 & 1 & 0 & 0 & -2 & 2 & 0 & 1 & 7 & -5 to -2 & 3 to 5 \\
\hline & $\begin{array}{l}\text { Mixed (conifer/ } \\
\text { broadleaf) }\end{array}$ & 0 & 0 & 4 & 2 & -2 to 2 & 4 & -3 & 3 & 3 & 3 & 3 & 3 & 27 & -5 to -3 & 22 to 24 \\
\hline & $\begin{array}{l}\text { Recently felled } \\
\text { mixed }\end{array}$ & 0 & 0 & 0 & 3 & -3 to 0 & 1 & 0 & 0 & -2 & 3 & 0 & 1 & 7 & -5 to -2 & 2 to 5 \\
\hline \multirow{9}{*}{ 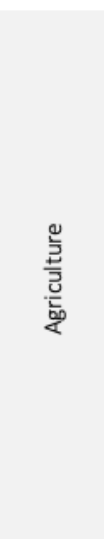 } & $\begin{array}{l}\text { Unimproved } \\
\text { grassland }\end{array}$ & 2 & 0 & 0 & 3 & -2 & 4 & -3 & 0 & -3 & 3 & 4 & 3 & 19 & -8 & 11 \\
\hline & $\begin{array}{l}\text { Semi-improved } \\
\text { grassland }\end{array}$ & 3 & 0 & 0 & 3 & -3 & 3 & -4 & 0 & -4 & 3 & 3 & 3 & 18 & -11 & 7 \\
\hline & $\begin{array}{l}\text { Improved } \\
\text { grassland }\end{array}$ & 4 & 0 & 0 & 3 & -4 & 3 & -4 & 0 & -5 & 4 & 2 & 3 & 19 & -13 & 6 \\
\hline & $\begin{array}{l}\text { Marshy } \\
\text { grassland }\end{array}$ & 2 & 0 & 0 & 3 & -2 & 4 & -3 & 0 & -3 & 2 & 4 & 3 & 18 & -8 & 10 \\
\hline & Ffridd & 2 & 0 & 0 & 3 & -2 & 4 & -3 & 0 & -3 & 2 & 4 & 3 & 18 & -8 & 10 \\
\hline & Heathland & 2 & 0 & 0 & 3 & -2 & 2 & -3 & 0 & -3 & 2 & 4 & 3 & 16 & -8 & 12 \\
\hline & $\begin{array}{l}\text { Tall Herb and } \\
\text { Fern }\end{array}$ & 1 & 0 & 0 & 3 & -2 & 2 & -3 & 0 & -3 & 2 & 3 & 2 & 13 & -8 & 15 \\
\hline & Mire & 2 & 0 & 0 & 4 & -2 & 3 & -3 & 0 & -3 to 3 & 2 & 4 & 2 & 20 & -8 to -5 & 12 to 15 \\
\hline & Arable & 0 & 3 & 0 & 3 & -4 & 1 & -3 & 0 & -5 & 3 & 2 & 2 & 14 & -12 & 2 \\
\hline
\end{tabular}

Figure 2: Qualitative assessment matrix: potential ecosystem service and dis-service supply from upland agricultural and forestry land use in Wales

An indication is given of the level of potential supply of the outlined ecosystem services by each land cover type within the two upland land uses using a relative five-point relative scale ranging from very low (1), low (2), moderate (3), high (4) to very high (5). In addition, for ecosystem dis-services this is shown using a negative five-point relative scale ranging from very low (-1), low (-2), moderate (-3), high (-4) to very high $(-5)$, finally 0 indicates no evidence of provision.

The scores included in this matrix are relative and should only be interpreted in relation to land cover types included in this assessment.

Where the ecosystem service has an ecosystem dis-service analogue and the particular land cover type has the capacity to supply either the ecosystem service or dis-service a range score from negative to positive is provided.

Uncertainty: An indication of the level of uncertainty surrounding the biophysical evidence of provision of the indicated ecosystem service is shown by the colour of the cell (see below) based on judgement by the authors on the basis of the evidence and/or theory examined for this assessment;

red = uncertain, evidence lacking, yellow = uncertain, contradictory evidence, green = established but evidence incomplete, light blue = well established, evidence in agreement and dark blue = certain, high consensus. 


\subsubsection{Spatial assessment of actual ecosystem service and dis-service supply}

Based on the subset of 12 ES and EDS for which demand could be spatially determined, the results of the spatial analysis further highlighted there is quite significant spatial variability in the level of ES supply from both land uses; this is because actual supply of many of the ES and EDS categories from both land uses are spatially dependent. For forestry land use there is a mix of moderate and high ES supply with areas of low supply - as shown in Figure 3, with the majority of larger parcels falling into the high potential ES supply category and the majority of smaller parcels falling into the low potential supply category. Generally, areas with high levels of ES supply from forestry are predominantly large contiguous

293 blocks of conifer. Conversely, the areas of forestry land use with lowest supply of ES are very small parcels

294 of predominantly amenity woodland within a matrix of agricultural land. For agricultural land use there 295 is a mix of moderate and high ES supply with some larger areas of low supply in the north of the region 296 as shown in Figure 3. The majority of agricultural land use parcels within the SDA fall into the moderate 297 ES supply category. There is no visibly discernible spatial pattern in the level of ES supply from agricultural 298 land use except that the areas of lowest supply are generally in the central high altitudinal spine of the 299 SDA. For EDS supply, there are a number of land cover parcels within forestry land use that are benign 300 with no supply of EDS, but there are areas of very low EDS supply from predominantly large blocks of 301 conifer, broadleaf and mixed woodland in the west of the region - as shown in Figure 4. Conversely the 302 majority of agricultural land use parcels within the SDA fall into the low EDS supply category with some 303 areas of moderate EDS supply which is contiguous with the extent of improved grassland within the SDA 304 - as shown in Figure 4. There is a spectrum of NES supply levels from forestry land use within the SDA; 305 from low through to high - as shown in Figure 5. Generally, the level of NES supply from forestry land use 306 increases as the size of the land cover parcel increases. Unsurprisingly, the level of NES supply from 307 agricultural land use is a mix of low and very low; the lowest levels of NES supply from agricultural land 308 use come from more improved agricultural land around the margins of the SDA - as shown in Figure 5. 309 Overall, the maps in Figure 3,4 and 5 show an imbalance in ES and EDS supply from forestry and 310 agricultural land use, with forestry land use outperforming agriculture across the board and specifically 311 with forestry significantly outperforming agricultural land use in terms of NES. 


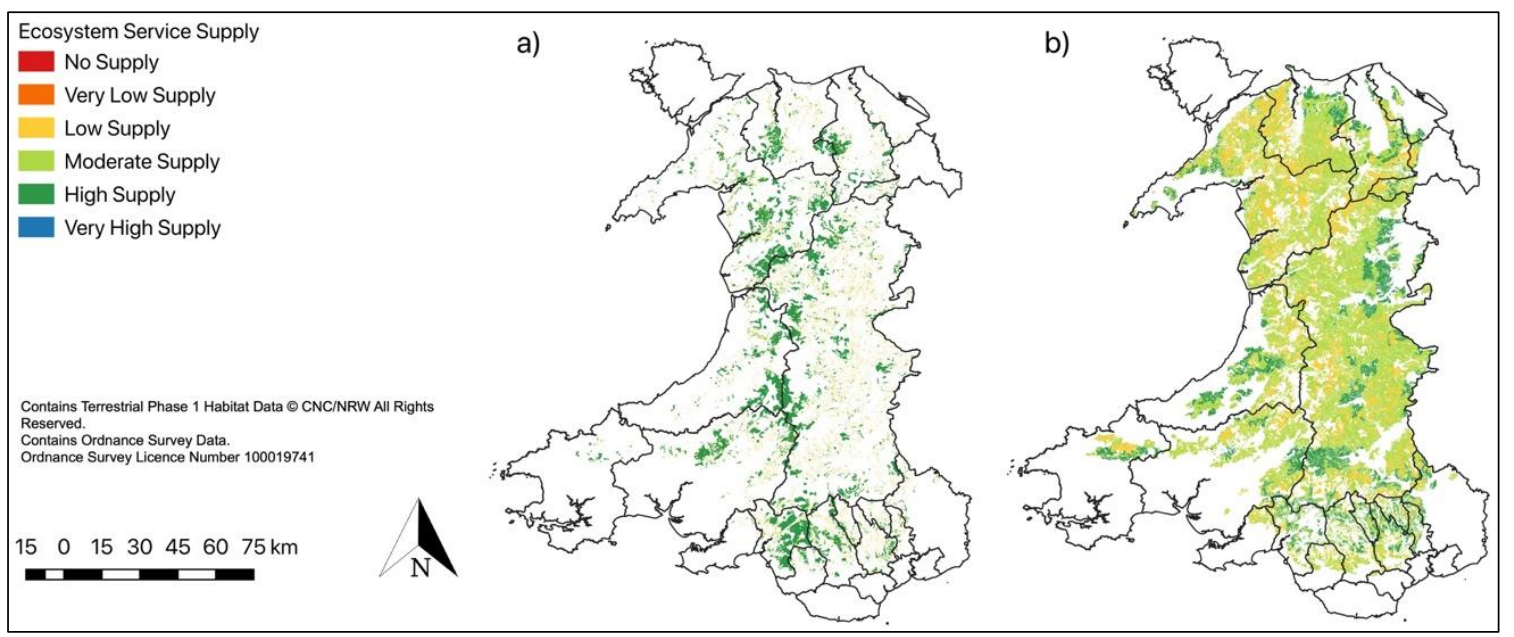

Figure 4: Ecosystem service supply from upland forestry and agricultural land use in Wales

a) Ecosystem service supply from upland forestry land use and b) ecosystem dis-service supply from upland agricultural land use in Wales. The ecosystem services comprise livestock production, arable crops, timber production, carbon sequestration, local flood risk mitigation, maintenance of potable water quality, employment and recreation. The maps were created using the following scale: $0=$ no supply, 1 to 6 = very low supply, 7 to $12=$ low supply, 13 to $18=$ moderate supply, 19 to $24=$ high supply and =>25= very high supply.

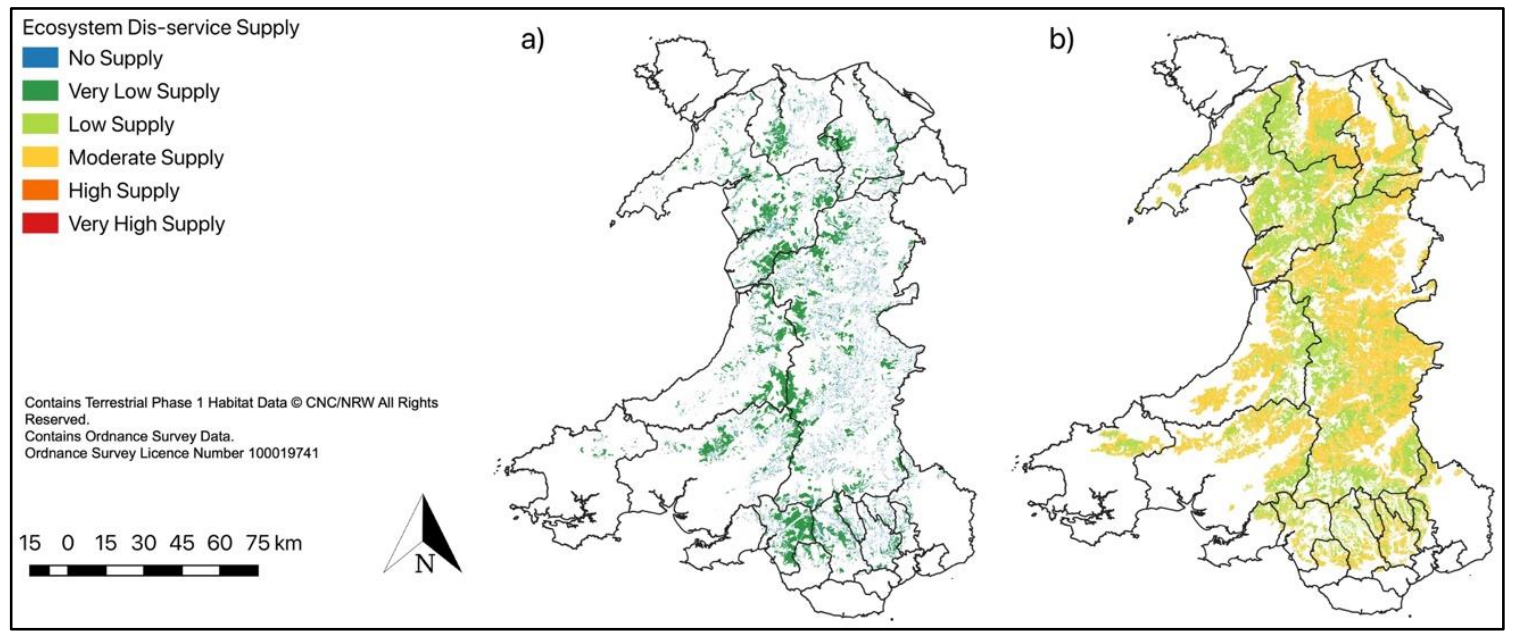

Figure 3: Ecosystem dis-service supply from upland forestry and agricultural land use in Wales

a) Ecosystem dis-service supply from upland forestry land use and b) ecosystem dis-service supply from upland agricultural land use in Wales. The ecosystem dis-services comprise increased local flood risk, GHG emissions and reduction of potable water quality. The maps were created using the following scale: $0=$ no supply, -1 to $-6=$ very low supply, -7 to $-12=$ low supply, -13 to $-18=$ moderate supply, -19 to $-24=$ high supply and $=<-25=$ very high supply. 


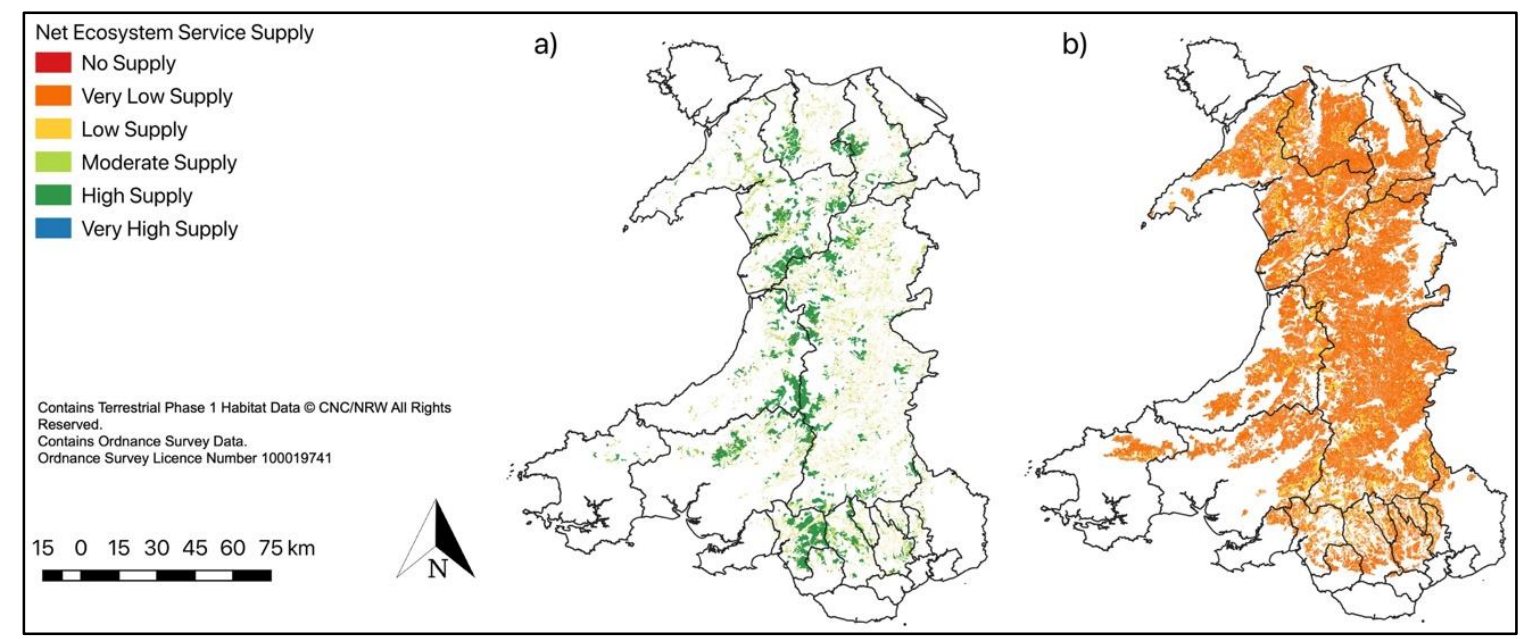

Figure 5: Net ecosystem service supply from upland forestry and agricultural land use in Wales

a) Net ecosystem service supply from upland forestry land use and b) ecosystem dis-service supply from upland agricultural land use in Wales. The net ecosystem service supply level comprises the supply of ecosystem services less the supply of ecosystem dis-services. The ecosystem services comprise livestock production, arable crops, timber production, carbon sequestration, local flood risk mitigation, maintenance of potable water quality, employment and recreation. The ecosystem dis-services comprise increased local flood risk, GHG emissions and reduction of potable water quality. The maps were created using the following scale: $0=$ no supply, 1 to $6=$ very low supply, 7 to 12 = low supply, 13 to $18=$ moderate supply, 19 to $24=$ high supply and =>25 = very high supply.

313

314

315

316

317

318

319

320

321

322

323

324

325

326

327

328

329

330

331

\subsection{Economic assessment and valuation}

Based on the subset of 9 ES and EDS with readily available valuation data the combined EV of ES benefits is $£ 1,472.25$ million year ${ }^{-1}$, EDS costs is $£ 101.54$ million year ${ }^{-1}$ and NES benefits is $£ 1,371.71$ million year ${ }^{-1}$ from the two dominant upland land uses in Wales combined - as shown in Table 2. It should be noted that the EV of EDS costs are orders of magnitude less than ES benefits. The EV of ES benefits from provisioning services is $£ 1,153.45$ million year ${ }^{-1}$, regulation and maintenance services is $£ 170.67$ million year ${ }^{-1}$ and cultural services is $£ 148.13$ million year ${ }^{-1}$. Provisioning services account for $78 \%$, regulation and maintenance services account for $12 \%$ and cultural services account for $10 \%$ of the total EV of ES benefits. Provisioning EDS costs are $£ 48.51$ million year ${ }^{-1}$ and regulation and maintenance EDS costs are $£ 53.03$ million year ${ }^{-1}$ accounting for $48 \%$ and $52 \%$ of the total EV of EDS costs respectively. Comparing the two land uses, the EV of ES benefits from agriculture is $£ 1,214.56$ million year ${ }^{-1}$ which is significantly higher than that of forestry at $£ 257.69$ million year ${ }^{-1}$ - as shown in Table 2.

On a per hectare basis the results are similar, the EV of ES benefits from agriculture at $f 1,434.02$ $\mathrm{ha}^{-1}$ year $^{-1}$ is higher than that of forestry at $£ 1,261.09$ ha $^{-1}$ year $^{-1}$ - as shown in Error! Reference source not found.. The EV of ES benefits from agriculture are $14 \%$ higher per hectare than forestry land use. The EV of EDS costs from agriculture is $£ 81.39$ million year ${ }^{-1}$ which is significantly higher than that of forestry at $£ 20.14$ million year ${ }^{-1}$. However on per hectare basis the EV of EDS costs from agriculture at $£ 96.10$ ha` $^{-}$ ${ }^{1}$ year $^{-1}$ is marginally lower $(2.5 \%)$ than that of forestry at $£ 98.58$ ha $^{-1}$ year $^{-1}$ but generally agriculture and forestry perform broadly similar in terms of EDS costs overall. 
333 million year ${ }^{-1}$, minimum EV of $£ 1,209.72$ million year ${ }^{-1}$ and maximum EV of $£ 1,771.01$ million year ${ }^{-1}$. The 334 results of the Monte Carlo simulation also showed a mean EV of EDS costs of $£ 101.33 \pm 10.90$ million year3351 , minimum EV of $£ 81.21$ million year ${ }^{-1}$ and maximum EV of $£ 121.47$ million year $^{-1}$. Consequently, the 336 Monte Carlo simulation showed a mean EV of NES benefits of $£ 1,389.49 \pm 124.26$ million year ${ }^{-1}$, minimum 337 EV of $£ 1,128.51$ million year ${ }^{-1}$ and maximum EV of $£ 1,649.54$ million year $^{-1}$. Overall a $20 \%$ variation in the 338 market and shadow prices of ES benefits and costs of EDS results in significant variability in the mean EV 339 of ES benefits, of EDS costs and of NES benefits and particularly between minima and maxima values.

340 Given the uncertainty in the market and shadow prices the results of the Monte Carlo simulation highlight 341 that our EV estimates fall within a potentially broad range and readers should be cognisant of this when 342 considering the results. For a full overview of the results of the sensitivity analysis (for individual 343 ecosystem service categories) see Supplementary Material Table 5.

344 Table 2: Economic value of ecosystem service benefits and dis-service costs from upland (agricultural and forestry) 345 land use in Wales (based on market and shadow prices as at 2018)

\begin{tabular}{|c|c|c|c|c|c|}
\hline \multirow{2}{*}{ Ecosystem services and dis-service } & \multicolumn{3}{|c|}{ Economic value ( $\mathrm{f}$ million year ${ }^{-1}$ ) } & \multicolumn{2}{|c|}{ Economic value $\left(f \text { ha }^{-1} \text { year }^{-1}\right)^{\text {a }}$} \\
\hline & Forestry & Agriculture & $\begin{array}{c}\text { Both land uses } \\
\text { combined }\end{array}$ & Forestry & Agriculture \\
\hline \multicolumn{6}{|l|}{ Provisioning services } \\
\hline Livestock production & $\mathrm{n} / \mathrm{a}$ & 517.59 & 517.59 & $n / a$ & 611.11 \\
\hline Arable crops & $\mathrm{n} / \mathrm{a}$ & 6.04 & 6.04 & $\mathrm{n} / \mathrm{a}$ & 7.13 \\
\hline Timber production & 40.13 & $\mathrm{n} / \mathrm{a}$ & 40.13 & 196.37 & $\mathrm{n} / \mathrm{a}$ \\
\hline $\begin{array}{l}\text { Water supply for consumptive use } \\
\text { Regulation and maintenance services }\end{array}$ & 114.71 & 475.00 & 589.70 & 561.37 & 560.82 \\
\hline Carbon sequestration & 56.80 & 108.83 & 165.63 & 277.95 & 128.50 \\
\hline Local flood risk mitigation & 5.04 & $\mathrm{n} / \mathrm{a}$ & 5.04 & 24.68 & $\mathrm{n} / \mathrm{a}$ \\
\hline \multicolumn{6}{|l|}{ Cultural services } \\
\hline Employment & 41.02 & 107.11 & 148.13 & 200.74 & 126.46 \\
\hline Ecosystem service benefits & 257.69 & $1,214.56$ & $1,472.25$ & $1,261.09$ & $1,434.02$ \\
\hline \multicolumn{6}{|l|}{ Provisioning dis-services } \\
\hline $\begin{array}{l}\text { Potable water quality reduction } \\
\text { Regulation and maintenance dis-services }\end{array}$ & 3.34 & 44.97 & 48.51 & 17.32 & 53.13 \\
\hline GHG emissions & 16.61 & 36.42 & 53.03 & 81.27 & 43.00 \\
\hline Ecosystem dis-service costs & 20.14 & 81.39 & 101.54 & 98.58 & 96.10 \\
\hline Ecosystem service benefits & 237.57 & $1,133.17$ & $1,371.71$ & $1,162.51$ & $1,337.92$ \\
\hline
\end{tabular}

\subsubsection{Economic values by land cover type}

347 The agricultural land cover type with the highest EV of ES benefits is Improved grassland $348\left(£ 1,902.66 \pm 70.95 \mathrm{ha}^{-1} \mathrm{year}^{-1}\right)$ and for forestry land use is coniferous woodland ( $£ 878 \pm 214.93 \mathrm{ha}^{-1} \mathrm{year}^{-}$

$349{ }^{1}$ ) - as shown in Figure 6. The agricultural land cover type with the highest EV of EDS costs is also semi 350 Improved grassland ( $£ 122.72 \pm 4.59 \mathrm{ha}^{-1}$ year $^{-1}$ ) and for forestry is also coniferous woodland ( $£ 127.11$ $351 \pm 18.63$ ha $^{-1}$ year $^{-1}$ ) - as shown in Figure 6 . Our results showed that there is greater variability in the supply 
352 and EV of ES benefits and EDS costs from forestry land use compared to agricultural land use, but that 353 both perform better in some location over others. Our results suggest that land use parcels with high 354 intensity of provisioning services supply (e.g. coniferous woodland, improved and semi-improved 355 grassland and arable) and consequently the highest EV of ES benefits are also the source of the highest 356 EV of EDS costs. For a full overview of the average economic values of the individual ES and EDS categories see Supplementary Material Table 6.

a) 2500

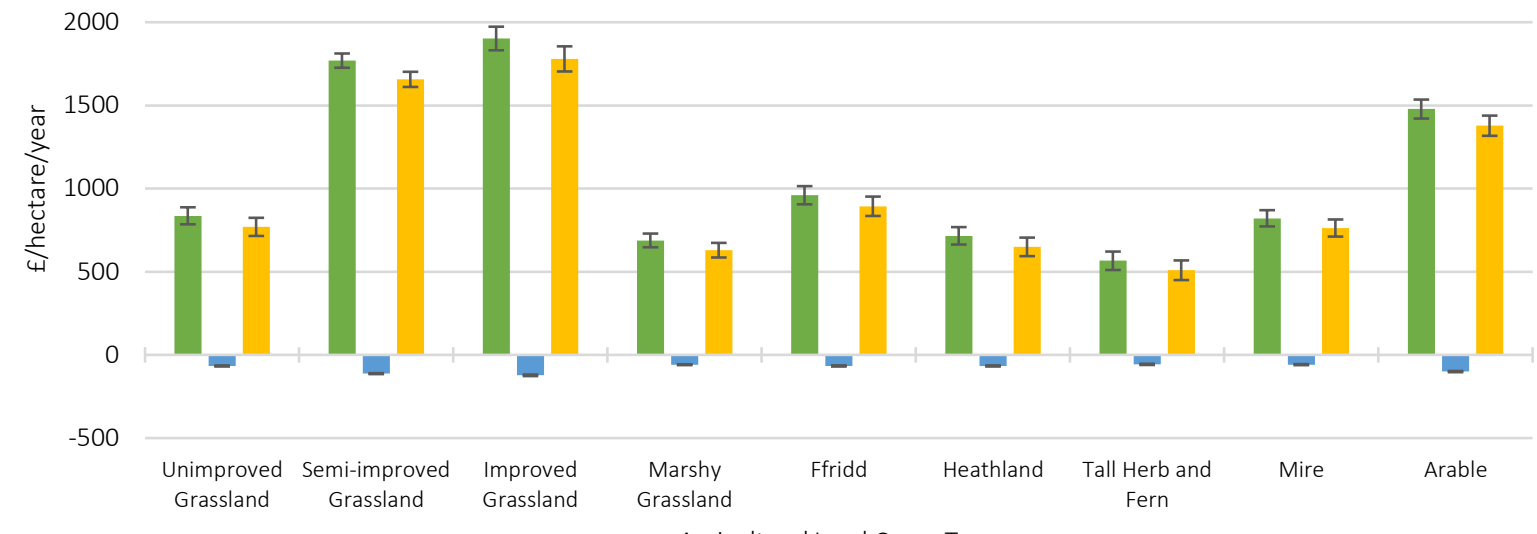

Agricultural Land Cover Type

b) 2500

2000

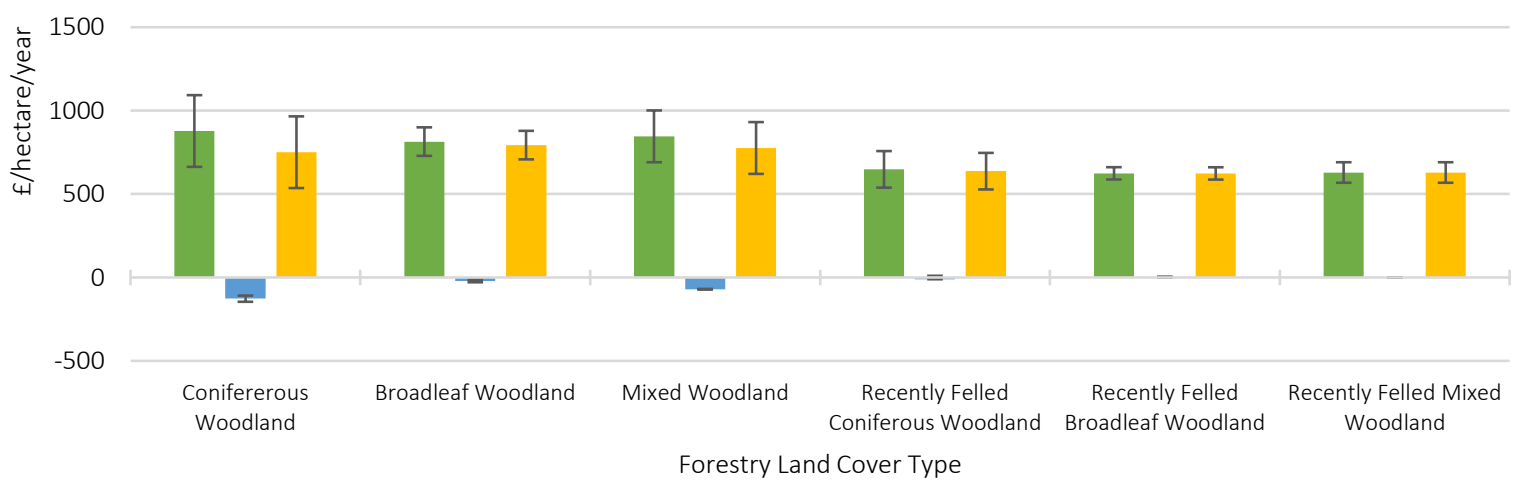

Ecosystem Service Benefits $\quad$ Ecosystem Dis-service Costs $\quad$ Net Ecosystem Service Benefits

Figure 6: Average economic value ha ${ }^{-1}$ year ${ }^{-1}$ of ecosystem service benefits, dis-service costs and net ecosystem service benefits by land cover type

Each column shows the marginal economic value $h a^{-1}$ of a) ecosystem service benefit and b) ecosystem dis-service costs from upland grassland and arable land cover types across each of the seven land sparing/sharing options. 


\subsubsection{Disaggregation into beneficiary specific bundles}

The disaggregation of the EVs into beneficiary group specific bundles showed that utilities companies are the recipient of the greatest annual EV of ES benefits ( $£ 589.99$ million year $^{-1}$ ) and rural communities outside the SDA receive the lowest EV of ES benefits ( $£ 0.004$ million year $\left.{ }^{-1}\right)$ - as shown in Figure 7. Global society is the recipient of the highest EV of EDS costs ( $£ 53.01$ million year $^{-1}$ ) conversely, private and public body landowners receive no EDS costs - as shown in Figure 7. The recipients of the greatest diversity of benefits $(n=4)$ are rural and urban communities within the SDA even though their beneficiary bundles are overall quite small. Our results suggest that a significant amount of the ES benefits is received by the two smallest beneficiary groups (private landowners and utility companies). For a full overview of the beneficiary bundles see Supplementary Material Table 7.
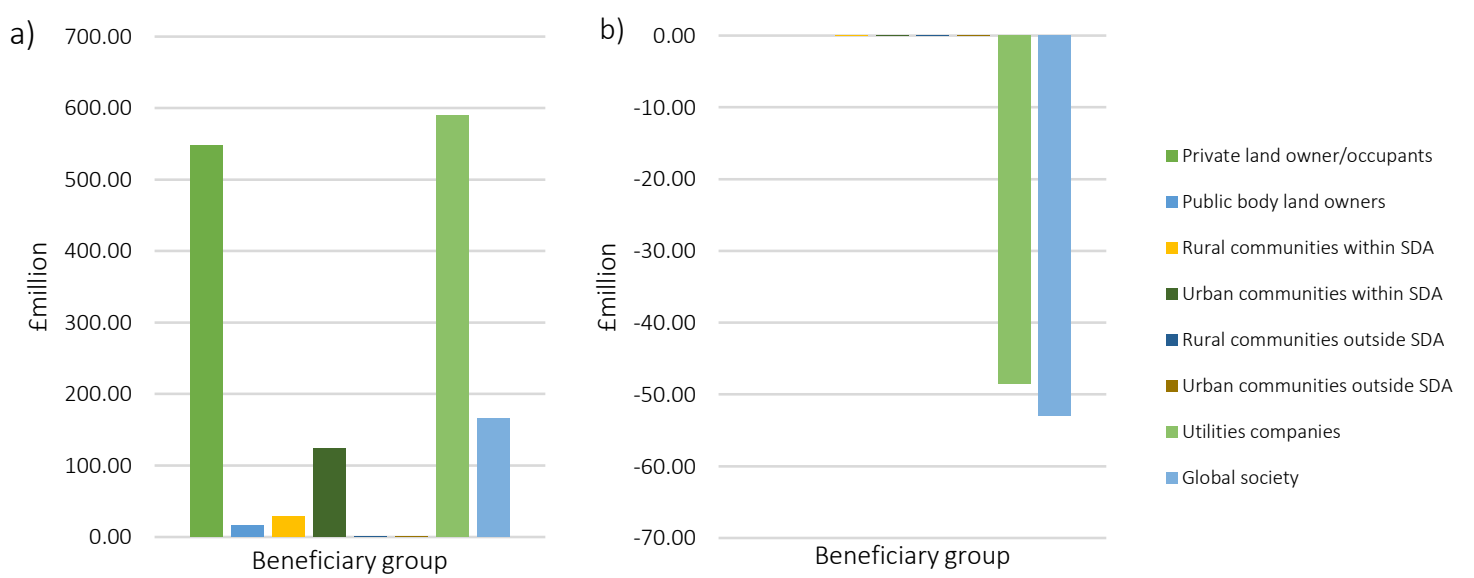

Figure 7: Disaggregation of the economic value of ecosystem service benefits and dis-service costs into beneficiary specific bundles.

The economic value of a) ecosystem service benefits and b) dis-service costs disaggregated into the bundles of benefits or costs received by each of the relevant beneficiary groups. The economic values are disaggregated by the relative population size of the beneficiary group.

\subsubsection{Spatial analysis of the economic value of ecosystem services and dis-services}

The results of our spatial analysis showed that the EV of ES benefits from agricultural land use is generally higher on more improved agricultural land in the eastern areas of the region; it is also evident that the EV of ES benefits from agricultural land use decreases on parcels located towards the central

372 higher altitudinal areas - as shown in Figure 8. Our spatial analysis also showed that the EV of ES benefits 373 from forestry land use is generally higher on larger parcels in the western areas of the region; it is also 374 evident that the EV of ES benefits from forestry land use decreases on parcels located towards eastern 375 areas - as shown in Figure 8, these are generally smaller parcels of amenity woodland within a matrix of 376 agricultural land. The areas supplying the highest EV of EDS costs from agricultural land use are located 377 in the lower altitudinal areas around the margins of the SDA- as shown in Figure 9. Our results showed 378 that the areas supplying the highest EV of EDS costs from forestry land use are located in western side of the SDA and are generally large parcels of conifers located in acid sensitive catchments - as shown in 
380 Figure 9. Unsurprisingly, the highest EV of NES benefits from agricultural land use comes from improved 381 agricultural land around the margins of the SDA - as shown in Figure 10; in particular the parcels with the 382 highest EV of NES benefits are located in the areas shaded blue (contiguous with the Severn Trent water 383 authority catchment). The highest EV of NES benefits from forestry land use comes from improved agricultural land around the central area of the SDA - as shown in Figure 10, in particular the parcels supply the highest EV of NES are located in the areas shaded green (also contiguous with the Severn Trent water authority catchment).

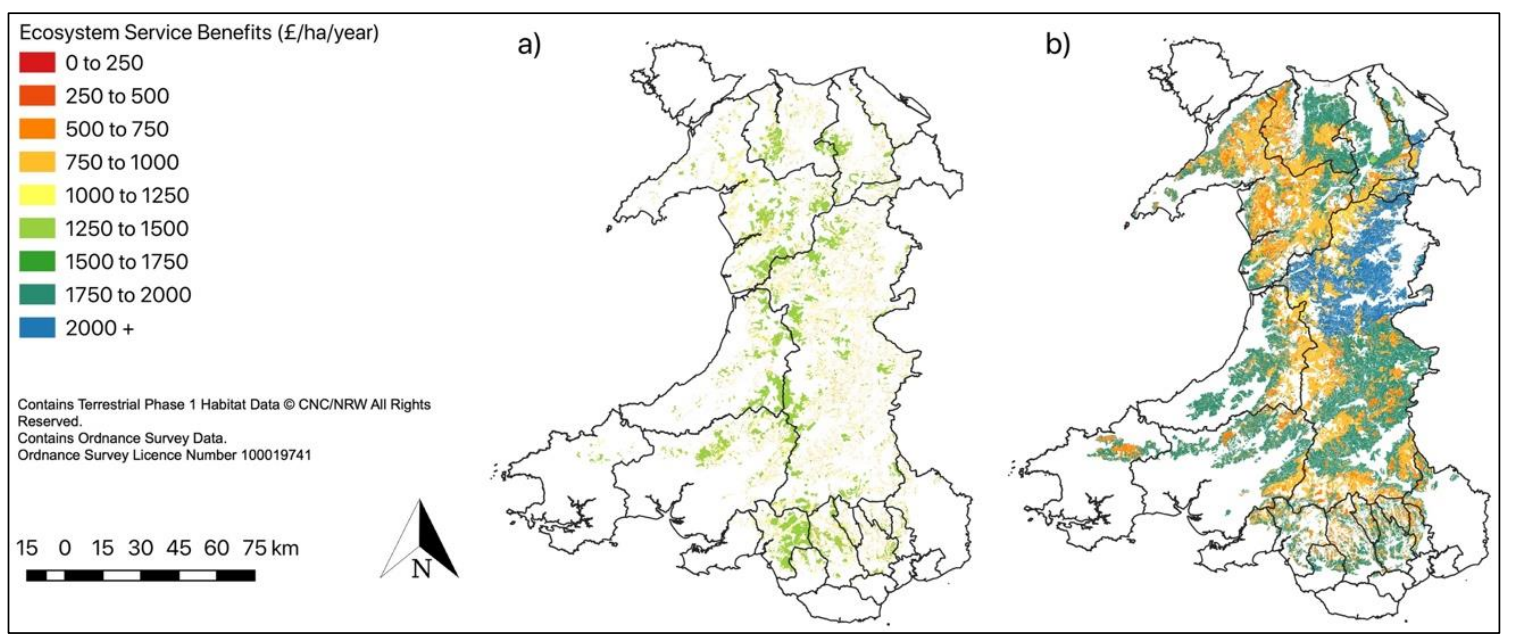

Figure 9: Economic value of ecosystem service benefits from upland forestry and agricultural land use in Wales

a) Economic value of ecosystem service benefits from upland agricultural land use and b) economic value of ecosystem service benefits from upland forestry land use in Wales. The economic value of ecosystem services comprises livestock production, arable crops, timber production, carbon sequestration, local flood risk mitigation and employment. All economic values are based on market and shadow prices correct as at 2018.

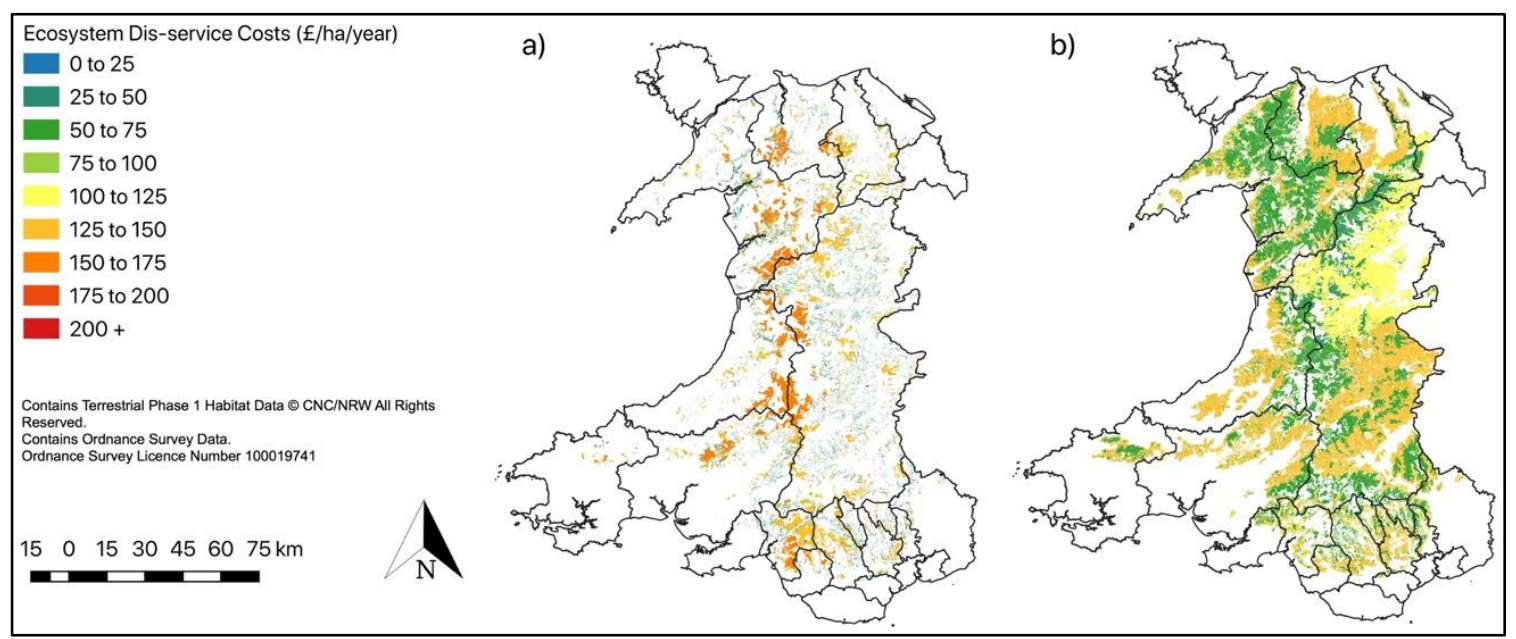

Figure 8: Economic value of ecosystem dis-service costs from upland forestry and agricultural land use in Wales

a) Economic value of ecosystem dis-service costs from upland forestry land use and b) economic value of ecosystem dis-service costs from upland agricultural land use in Wales. The economic value of ecosystem dis-services comprises GHG emissions and reduction of potable water quality. All economic values are based on market and shadow prices correct as at 2018. 


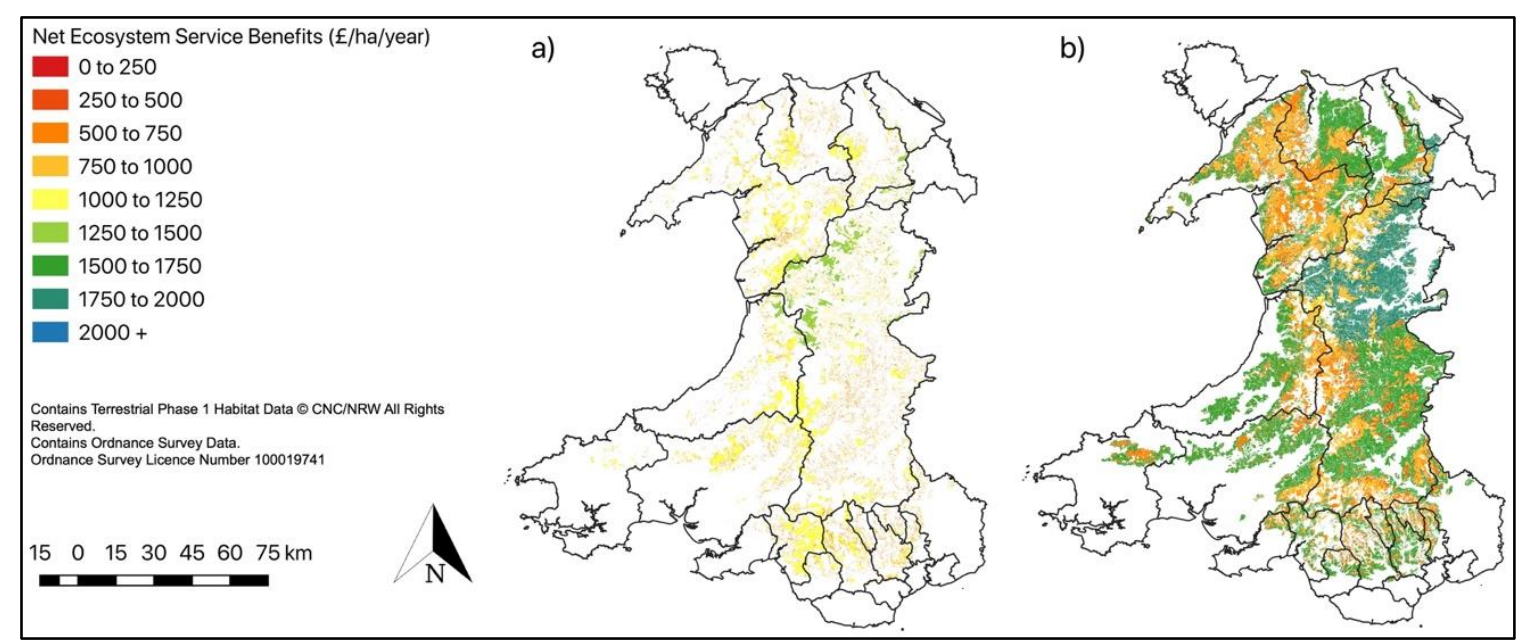

Figure 10: Economic value of net ecosystem service benefits from upland forestry and agricultural land use in Wales

a) Economic value of net ecosystem service benefits from upland forestry land use and b) economic value of net ecosystem service benefits from upland agricultural land use in Wales. The economic value of net ecosystem services comprises the economic value of ecosystem service benefits less the economic value of ecosystem dis-service costs. The economic value of ecosystem services comprises livestock production, arable crops, timber production, carbon sequestration, local flood risk mitigation and employment. The economic value of ecosystem dis-services comprises GHG emissions and reduction of potable water quality. All economic values are based on market and shadow prices correct as at 2018.

\section{Discussion}

In this study we explored the supply of a subset of ES from upland agricultural and forestry land use in Wales and the EV of their benefits. We also moved beyond many existing valuation studies (Eftec, 2010; Europe Economics, 2017; Willis et al., 2003) by also explicitly considering the supply of EDS and the

391 EV of their costs. Rather than basing our assessment on solely the presence and amount of a particular 392 land use as a determinant of ES we produced spatially explicit estimates of the supply and EV of ES 393 benefits and EDS costs by considering the presence of demand for ES and the location of land use in the 394 welsh uplands as determinants of ES and EDS provision. Considering the spatial heterogeneity of the 395 study area and the supply of ES and EDS our simple spatially explicit approach taken in this study is an 396 improvement on similar work undertaken in Wales. Our research which is guided by systematic consideration of the ES and EDS included within the integrated qualitative and economic assessments provides a more nuanced overview of the value of current land use operating in the Welsh uplands. We capture the benefits of upland land use in Wales and, more importantly the likely beneficiaries to which

400 these benefits accrue. We also capture some EDS which are seldomly captured in these types of study 401 and show where these costs accrue.

402 Our integrated qualitative assessment and economic valuation suggests that land use in the 403 Welsh uplands supplies a range of valuable benefits from ES, but alongside the significant level of 404 economic benefits there are significant costs that also accrue from EDS. The inclusion of EDS provides greater nuance when comparing the values used in other studies and highlights where agriculture and forestry is performing relatively well and where they are underperforming. In interpreting this data, we 
need to be cognisant of the considerable data gaps around key ES (particularly cultural values and some

408 additional regulation and maintenance ES). So whilst like earlier work carried out in the UK (Eftec, 2010;

409 Europe Economics, 2017; Saraev et al., 2017; Willis et al., 2003) our study also shows there is a significant

410 supply of ES and EV of ES benefits from forestry land use, we also demonstrate this is not always the case

411 with some areas of forestry land use supplying EDS. Similarly like Pretty et al., (2000) our study

412 demonstrates that upland agriculture in Wales is the source of EDS costs but it also supplies a significant

413 level of ES supply and EV of ES benefits. Overall our results highlight imbalance in the delivery of

414 ecosystem services and dis-services from the two dominant upland land use in Wales.

415

4164.1 Imbalanced contributions of forestry and agricultural land use to the economic value of net 417 ecosystem service benefits

418 If we consider the supply of NES in qualitative terms and particularly the maps in Figure 5, our 419 results suggest that the net benefits of forestry far exceed agricultural land use. This is because when ES 420 and EDS are unweighted and their supply considered equally, the EDS supply from agriculture cancels out 421 the ES supply leading to a very significant imbalance between the net benefits of forestry and agriculture.

422 It is worth noting that this is in some part to do with additional ES (potable water quality maintenance 423 and livestock shelter and shade) supplied by forestry land use and additional EDS (increased local flood 424 risk) supplied by agricultural land use. When an economic weighting is applied to the supply of ES and 425 EDS, the imbalance in supply between agricultural and forestry land use is not as strikingly obvious (as 426 shown in Figure 10). Contrary to the qualitative approach, the results of the quantitative monetary 427 analysis suggest that the NES benefits from agricultural land use are higher than forestry land use both 428 in absolute and relative terms; per hectare agricultural land use outperforms forestry by $15 \%$ in terms of 429 NES benefits.

430 As both forestry and agricultural land use perform broadly similar in terms of the EV of EDS costs 431 the main reason for agricultural land use outperforming forestry land use overall is the greater 432 provisioning value of the former compared to the latter. Per hectare the EV of provisioning services from 433 agricultural land use $\left(£ 1,179.06 \mathrm{ha}^{-1}\right.$ year $\left.^{-1}\right)$ is $36 \%$ higher than that of forestry $\left(£ 757.72\right.$ ha $^{-1}$ year $\left.{ }^{-1}\right)$. 434 Conversely, forestry land use does perform significantly better than agricultural land use in terms of the 435 per hectare EV of regulation and maintenance services. Forestry land use delivers $£ 503.37 \mathrm{ha}^{-1} \mathrm{year}^{-1}$ of 436 regulation and maintenance ES which is $57 \%$ higher than agricultural land use $\left(£ 254.96\right.$ ha $\left.^{-1} y^{-a}{ }^{-1}\right)$. While 437 our results suggest that the overall benefits from agricultural land use are higher than for forestry land 438 use; most of this is tied up in provisioning benefits whereas forestry land use contributes greater 439 additional benefits (regulation and maintenance) on top of provisioning benefits. Exploring the results 
440 further, the imbalanced delivery of ES and EDS is highlighted by a) the split between public and private 441 benefits and $b$ ) the distribution of benefits amongst beneficiaries.

\subsubsection{Imbalance of public and private benefits and costs of upland land use in Wales}

If we look at the results in terms of the split between public and private benefits this imbalance is illustrated further. Across the two land uses combined the private benefits (livestock, arable, timber production and employment) exceed the public benefits (e.g. carbon sequestration and flood risk mitigation). The private benefits and contribution directly to the economy (i.e. the amount of private monetary benefits that actually passes through physical markets) is $£ 1,301.87$ Million year ${ }^{-1}$ or $88 \%$ of the total ES benefits, of which water supply for consumptive use accounts for largest single portion at $45 \%$. This means that only $12 \%$ of the EV ( $£ 170.67$ Million year $\left.^{-1}\right)$ of ES benefits are public benefits and do not arise through market transactions. Our results suggest that the public costs outweigh the private costs, however it should be noted that this is only by a margin of $4 \%$. The negative impact of upland land use in Wales on the economy (i.e. the amount of private monetary costs that accrue to private individuals or organisations) amounts to $£ 48.51$ Million year ${ }^{-1}$ or $48 \%$ of the total EV of EDS costs of which all private

455 EDS costs comes from reduction of potable water quality from primarily agricultural land use. In 456 comparison, the EV of public EDS costs from upland land use in Wales are marginally higher at $£ 53.03$ 457 Million year-1 meaning that $52 \%$ of EDS costs are not visible in market transactions. Unsurprisingly the majority of public EDS costs come from GHG emissions associated with primarily livestock emissions as well as agricultural operations due to a larger area under agricultural land use, furthermore hectare for hectare the GHG emissions from forestry operations are higher ( $£ 81.27$ ha $^{-1}$ year $\left.{ }^{-1}\right)$ than the equivalent figure for agriculture ( $\left.£ 43 \mathrm{ha}^{-1} \mathrm{year}^{-1}\right)$.

When comparing agricultural and forestry land use the balance between private and public benefits is askew and our results suggest that greater public benefit is derived from forestry land use in the Welsh uplands. Around 23\% of the ES benefits from forestry land use are public benefits realised through relatively high supply levels of regulation and maintenance services. Conversely for agricultural

466 land use only 9\% of the ES benefits are public benefits due to lower supply levels of regulation of 467 maintenance services compared to much higher levels of provisioning services. Interestingly under 468 forestry land use the majority (82\%) of the EDS costs and public whereas under agricultural land use over 469 half (55\%) are private. Consequently, there is scope to increases the provision of public benefits upland 470 land use in Wales as a whole increase the public benefits of agricultural land use closer to the level 471 supplied by forestry land use. Whilst the EV of EDS costs are orders of magnitude lower than while also 472 reducing both public and private EDS costs from the upland land use in Wales. 

between different stakeholders or beneficiaries. Most existing studies aggregate the separate values of individual ES into a single figure cited as the total societal benefits derived from the particular study site (Eftec, 2010; Europe Economics, 2017; Saraev et al., 2017; Willis et al., 2003). This overlooks issues surrounding the distribution of benefits across the spectrum of different beneficiary groups (Hein et al., 2006). ES and EDS are emergent properties of SES (Berkes and Folke, 1998; McGinnis and Ostrom, 2014;

480 Ostrom, 2009) and different ES or EDS arise at different social scales (Hein et al., 2006), hence the value 481 of ES benefits and costs of EDS derived will differ across the spectrum of beneficiaries. Accordingly, we 482 explored the distribution of our total aggregated values across the spectrum of relevant beneficiary 483 groups. Our results suggest that utilities companies directly gain the largest bundle of ES benefits from 484 upland land use in Wales through water supply for consumptive use benefits. Second to the utilities 485 companies, our results highlight that a significant level of ES benefits directly accrue to private 486 landowners due the high levels of provisioning services. By comparison the beneficiary bundles of the 487 urban and rural populace are quite small as shown in Figure 7. This highlights a further imbalance in ES 488 supply, notably that the majority of the ES benefits are received directly by a relatively small group of 489 beneficiaries. That being said, the direct benefits accruing to the utilities companies and private 490 landowners are ultimately passed on indirectly through the value chain to other beneficiary groups (such as the rural and urban populace).

Our results also suggest that the majority of the EDS costs are directly accrued publicly by global society through primarily GHG emissions, the water companies. In addition, the urban and rural populace

494 of Wales are also indirectly affected by the private EDS costs accruing to the utilities companies through reduction to potable water quality as these costs are more often than not indirectly passed on to the general public through increases in utility bills. This study has indicated that even though utilities companies and private land owners and occupants receive the lion's share of the economic benefits of upland land use and have the largest overall individual vested financial interest global society as well as urban and rural communities in Wales are equally important stakeholders by directly or indirectly receiving the largest amount of EDS costs.

\subsection{Identifying an opportunity space for rebalancing ecosystem service provision}

The results of our analysis raise an interesting question, might increases in tree cover within upland agricultural land use in Wales address the imbalances highlighted in Sections 4.1.1 and 4.1.2. More specifically, would increasing tree cover on agricultural land increase the public benefits as well as 
507 Welsh government aims for significant expansion of tree cover (Forestry Commission Wales, 2009; 508 National Assembly for Wales, 2017; UKCCC, 2017), perhaps the GIS maps are most useful in identifying 509 an opportunity space to rebalance ES supply and minimise EDS through transfers of land use out of 510 agriculture or adaptions of agricultural land use. The spatially explicit information provided by our maps 511 permits identification of the locations and land cover types providing the highest supply and costs of EDS.

512 For agricultural land use it can be observed that the areas of highest supply EDS costs are located in valley 513 bottom areas and lower altitudinal ranges. More specifically, increasing agricultural improvement leads 514 to higher supply and costs of EDS (i.e. EDS is higher from improved grassland than for heathland). Likewise 515 increasing agricultural improvement leads to a higher-level provisioning benefits relative to regulation 516 and maintenance benefits. When considered alongside Figure 1 the maps in Figures 3,4 and 5 along with 517 Figures 8,9 and 10 show that unimproved, semi-improved and improved grassland along with arable land 518 present an opportunity space for adaptions and transformation of land use to reduce the supply and EV 519 of EDS costs along with increasing the provision of public benefits. That being said, there is a major trade 520 off clearly evident when the potential implications of this are considered in light of the EV of cultural ES; 521 whilst the value of employment benefits in monetary terms is lower for agricultural land use than forestry 522 the number of FTE jobs from agricultural land use is significantly higher than for forestry. Readers should 523 be cognisant of the fact major reductions in agricultural land use in favour of increases in woodland cover 524 may increase public ES benefits and reduce EDS costs but will have significant impacts on rural 525 communities and dilute the number of livelihoods attached to management of land within the Welsh uplands. The impacts of increasing woodland cover within the Welsh uplands on ES and EDS requires further analysis and consideration in order to inform future decision making and policy. It should be noted that the assessment and mapping approach taken in this study is not at a sufficiently fine resolution to assess the potential ES benefits of more integrated forms of land use such as agroforestry and riparian 530 planting.

\section{$532 \quad 4.3$ Highlighted knowledge gaps}

Our study has highlighted some important knowledge gaps. Generally, there is a good level of evidence relating to the biophysical processes and mechanistic understanding of ES and EDS generation, but the usefulness of these existing studies is severely hindered. Linking the biophysical processes associated with land use to the EV of ES and EDS is difficult as the biophysical evidence and economic valuations are often in differing units (e.g. water quality reduction in biophysical studies reported in units of chemical loading and in economic studies it is reported in WTP/WTA per unit length of clean/contaminated river) or not spatially explicit. This is particularly evident in Table 1 where it can be 
541 parcels is incomplete or existing relevant valuation data is not available. At a Wales wide level there is a

542 lack of sufficient existing valuation data available for valuing some of the ecosystem services and dis543 services omitted from this study without undertaking extensive primary valuation studies (See Table 1).

544 Currently very little is known about the EV of ES benefits and EDS costs in Wales and in a wider UK context 545 that can be used in a spatially explicit benefits transfer based valuation of multiple ES and EDS such as 546 this. In addition, Wales is a country that is biophysical data rich at plot and national level, but data scarcity 547 increases at scales between plot and national level (e.g. regional, specifically the SDA), this makes 548 complete assessment of ES and EDS from specifically upland land use extremely difficult. The data gaps 549 linking underlying physical processes and ES and EDS that arise to economic impacts are particularly 550 evident for some quite important ES (water quality maintenance, recreation, landscape amenity and 551 diversity) and EDS (increased local flood risk) therefore, no desk-based assessment exercise such as this

552 will be near to complete unless these data and knowledge gaps are addressed.

553

\section{4.4 Caveats of the present study}

555 Due to the previously noted data gaps it is currently not possible to undertake a complete assessment of the full extent of the ES and EDS supplied by upland land use in Wales. As such this study is based on a subset of the CICES classification. Furthermore, the economic valuation aspect of this study is subject to four corollary caveats when considering the findings. Firstly, the economic valuation of ES and EDS is not without flaws, from a methodological standpoint the EV of ES benefits and EDS costs can vary significantly across the range of valuation methods (Spangenberg and Settele, 2016, 2010) and is highly sensitive to the biophysical and economic data used in the calculations. Secondly, we limited the economic valuation to ES and EDS for which there was available biophysical and existing pricing and valuation data. Furthermore, as we deviated from the TEV framework and focussed our valuation on use

564 values, the economic values reported in this study are not the full value or costs of ES and EDS from 565 upland land use in Wales. Thirdly, due to the use of pricing-based methods (although appropriate for 566 pragmatic studies such as this with limited existing valuation data, limited resources and temporal 567 constraints), the full welfare impacts (i.e. consumer surpluses) of ES and EDS from upland land use in 568 Wales will likely be underestimated. Finally, Inclusion of the additional ES - for which valuation data was 569 not available for this study -into the economic valuation would probably increase the EV of ES benefits 570 and EDS costs. If the ES benefits of cultural ES (recreation and landscape amenity and diversity) could be quantified in monetary terms the beneficiary bundles of very important beneficiary groups within wales (rural and urban communities) would also increase significantly. 


\section{Conclusions}

Attempts to influence and change patterns of land use requires a baseline assessment of the prevailing usage. In this study we developed a simple low data input spatially explicit methodology to estimate the supply and EV of ES benefits and EDS costs from the two dominant land use in the Welsh uplands. Our methodology has built on earlier work integrating biophysical data and economic output values with spatially explicit indicators of demand for ES and EDS to represent flows of ES and EDS from the Welsh uplands. Our results suggest that upland land use in the Welsh uplands supplies a significant level of ES benefits, alongside which are supplied a considerable level of EDS costs. Agricultural land use contributes the greatest proportion of the total ES benefits most of which are delivered through high levels of provisioning service benefits. Conversely, forestry land use supplies a far higher level of public

584 ES benefits than agricultural land use. Agricultural land use does also supply the lion's share of EDS. The greatest ES benefits with no associated EDS costs are derived from broadleaf and mixed woodland within the SDA suggesting increased in these and cover types may be beneficial in increasing the level of public benefits from upland land use in Wales. Our disaggregated totals across the spectrum of beneficiary groups shows that the greatest ES benefits are received by the utilities companies and global society is the recipients of the highest amount EDS. Our results show that rural and urban communities within the SDA benefit from a disproportionately low level of ES benefits however other important ES benefits that might accrue to them cannot be fully quantified in monetary terms yet. Overall our results highlight a significant imbalance in the delivery of ecosystem services and dis-services from upland land use in Wales, notably underperformance in the provision of public goods from upland land use in Wales when agricultural and forestry land use are considered together and particularly from agricultural land use alone. Finally, while we acknowledge that this study is not fully comprehensive with respect to the full spectrum of ES and EDS, we do feel that it represents an improvement on the current evidence base surrounding the impacts of land use in Wales on ES and EDS available to policy and decision makers.

\section{Funding sources and Acknowledgements}

This paper was funded as part of the Knowledge Economy Skills Scholarships (KESS 2) a pan-Wales higher level skills initiative led by Bangor University on behalf of the higher education sector in Wales. It is part funded by the Welsh Government's European Social Fund (ESF) convergence programme for West

603 Wales and the Valleys. This paper was funded as part of a collaboration between KESS 2 and Coed Cymru 604 and the author would like the thank Coed Cymru for their support of the PhD project of which this paper 605 forms part. We would also like to thank the two anonymous reviewers for their time along with their very 606 helpful comments and suggestions that have improved this piece of work. 


\section{References}

609 Armstrong, E., 2016. The Farming Sector in Wales.

610 Bateman, I.J., Lovett, A.A., 2000. Estimating and valuing the carbon sequestered in softwood and hardwood trees, timber products and forest soils in Wales. J. Environ. Manage. 60, 301-323. https://doi.org/10.1006/jema.2000.0388

613

614

615

616

617

618

619

620

621

622

623

624

625

626

627

628

629

630

631

632

633

634

635

636

637

638

639

640

641

642

643

644

645

646

647

648

649

650

Bateman, I.J., Mace, G.M., Fezzi, C., Atkinson, G., Turner, R.K., 2014. Economic analysis for ecosystem service assessment, in: Ninan, K.N. (Ed.), Valuing Ecosystem Services. Methodological Issues and Case Studeis. Edward Elgar Publishing, Cheltenham, pp. 78-89.

Berkes, F., Folke, C., 1998. Linking socioecological and ecological systems: Management practices and social mechanisms for building resilience. Cambridge University Press, New York.

Blanco, J., Dendoncker, N., Barnaud, C., Sirami, C., 2019. Ecosystem disservices matter: Towards their systematic integration within ecosystem service research and policy. Ecosyst. Serv. 36, 100913. https://doi.org/10.1016/j.ecoser.2019.100913

Bonn, Aletta, Rebane, M., Reid, C., 2009. Ecosystem services: a new rationale for conservation of upland environments, in: Bonn, A, Allott, T., Hubacek, K., J Stewart (Eds.), Drivers of Environmental Change in Uplands. Routledge, Abingdon, pp. 448-474.

Brainard, J., Bateman, I.J., Lovett, A.A., 2009. The social value of carbon sequestered in Great Britain's woodlands. Ecol. Econ. 68, 1257-1267;; https://doi.org/10.1016/j.ecolecon.2008.08.021

Burkhard, B., Kroll, F., Müller, F., 2010. Landscapes' Capacities to Provide Ecosystem Services - a Concept for Land-Cover Based Assessments. Landsc. Online 15, 1-22. https://doi.org/10.3097/LO.200915

Burkhard, B., Kroll, F., Nedkov, S., Müller, F., 2012. Mapping ecosystem service supply, demand and budgets. Ecol. Indic. 21, 17-29. https://doi.org/10.1016/j.ecolind.2011.06.019

Dasgupta, P., 2008. Nature in economics. Environ. Resour. Econ. 39, 1-7. https://doi.org/10.1007/s10640-007-9178-4

de Groot, R.S., Alkemade, R., Braat, L., Hein, L., Willemen, L., 2010. Challenges in integrating the concept of ecosystem services and values in landscape planning, management and decision making. Ecol. Complex. 7, 260-272. https://doi.org/10.1016/j.ecocom.2009.10.006

Dickie, M., 2003. Defensive Behaviour and Damage Cost Methods, in: Champ, P.A., Boyle, K.J., Brown, T.C. (Eds.), A Primer on Nonmarket Valution. Kluwer Academic Publishers, Dordrecht, pp. 395444.

Dixon, J.A., Scura, L.F., Carpenter, R.A., P. B. Sherman, 1997. Economic Analysis of Environmental Impacts. Earthscan, London.

Dunn, R.R., 2010. Global mapping of ecosystem disservices: the unspoken reality that nature sometimes kills us. Biotropica 42, 555-557. https://doi.org/10.1098/rspb.2010.0340.F

Eftec, 2010. The economic contribution of the public forest estate in England.

Europe Economics, 2017. The Economic Benefits of Woodland.

Evans, M., 2009. Natural changes in upland landscapes, in: Bonn, A., Allott, T., Hubacek, K., Stewart, J. (Eds.), Drivers of Environmental Change in Uplands. Routledge, Abingdon, pp. 13-33.

Ferrini, S., Schaafsma, M., Bateman, I.J., 2015. Ecosystem Services Assessments and Benefit Transfer, in: Johnston, R.J., Rosenberger, R.S., Brouwer, R. (Eds.), Benefit Transfer of Environmental and Resource Values. Springer, Dordrecht, pp. 307-328. https://doi.org/10.1007/978-94-017-9930-0

Fezzi, C., Bateman, I., Askew, T., Munday, P., Pascual, U., Sen, A., Harwood, A., 2014. Valuing 
Provisioning Ecosystem Services in Agriculture: The Impact of Climate Change on Food Production in the United Kingdom. Environ. Resour. Econ. 57, 197-214. https://doi.org/10.1007/s10640-0139663-x

Fisher, B., Turner, K., Zylstra, M., Brouwer, R., Groot, R. De, Farber, S., Ferraro, P., Green, R., Hadley, D., Harlow, J., Jefferiss, P., Kirkby, C., Morling, P., Mowatt, S., Naidoo, R., Paavlova, J., Strasssburg, B., Yu, D., Balmford, A., 2008. Ecosystem Services and Economic Theory : Integration for PolicyRelevant Research. Ecol. Appl. 18, 2050-2067. https://doi.org/10.1890/07-1537.1

Fisher, B., Turner, R.K., Morling, P., 2009. Defining and classifying ecosystem services for decision making. Ecol. Econ. 68, 643-653. https://doi.org/10.1016/j.ecolecon.2008.09.014

Flores, N.E., 2003. Conceptual Framework for Nonmarket Valuation, in: Champ, P.A., Boyle, K.J., Brown, T.C. (Eds.), A Primer on Nonmarket Valution. Kluwer Academic Publishers, Dordrecht, pp. 27-58.

Forestry Commission Wales, 2009. Woodlands for Wales.

Freeman, M., 2003. The measurement of environmental and resource values: theory and methds. Routledge, Washington DC.

Goldenberg, R., Kalantari, Z., Cvetkovic, V., Mörtberg, U., Deal, B., Destouni, G., 2017. Distinction, quantification and mapping of potential and realized supply-demand of flow-dependent ecosystem services. Sci. Total Environ. 593-594, 599-609. https://doi.org/10.1016/j.scitotenv.2017.03.130

Haines-Young, R., Potschin-Young, M.B., 2018. Revision of the Common International Classification for Ecosystem Services ( CICES V5.1): A Policy Brief. One Ecosyst. 3, 1-6. https://doi.org/10.3897/oneeco.3.e27108

Haines-Young, R., Potschin, M., 2017. Common International Classification of Ecosystem Services (CICES) V5.1 and Guidance on the Application of the Revised Structure.

Haines-Young, R., Potschin, M.B., 2010. The links between biodiversity, ecosystem services and human well-being, in: Raffaelli, D., Frid, C. (Eds.), Ecosystem Ecology: A New Synthesis, BES Ecological Reviews Series, Ecosystem E. Cambridge.

Hardaker, A., 2018. Is forestry really more profitable than upland farming? A historic and present day farm level economic comparison of upland sheep farming and forestry in the UK. Land use policy 71, 98-120. https://doi.org/10.1016/j.landusepol.2017.11.032

Hein, L., van Koppen, K., de Groot, R.S., van lerland, E.C., 2006. Spatial scales, stakeholders and the valuation of ecosystem services. Ecol. Econ. 57, 209-228. https://doi.org/10.1016/j.ecolecon.2005.04.005

Howarth, R.B., Farber, S., 2002. Accounting for the value of ecosystem services. Ecol. Econ. 41, 421429. https://doi.org/10.1016/s0921-8009(02)00091-5

Hubacek, K., Beharry, N., Bonn, A., Burt, T., Holden, J., Ravera, F., Reed, M., Stringer, L., Tarrason, D., 2009. Ecosystem Services in Dynamic and Contested Landscapes: The Case of UK Uplands, in: Winter, M., Lobley, M. (Eds.), What Is Land for? The Food, Fuel and Climate Change Debate. Earthscan, London, pp. 167-186.

Hubbard, C., Davis, J., Feng, S., Harvey, D., Liddon, A., Moxey, A., Ojo, M., Patton, M., Philippidis, G., Scott, C., Shrestha, S., Wallace, M., 2018. Brexit: How Will UK Agriculture Fare? EuroChoices 17, 19-26. https://doi.org/10.1111/1746-692X.12199

Johnston, R.J., Wainger, L.A., 2015. Benefit Transfer for Ecosystem Service Valuation: An Introduction to Theory and Methods, in: Johnston, R.J., Rosenberger, R.S., Brouwer, R. (Eds.), Benefit Transfer of Environmental and Resource Values. Springer, Dordrecht, pp. 237-274. https://doi.org/10.1007/978-94-017-9930-0 
Mansfield, L., 2011. Upland Agriculture and the Environment. Badger Press, Bowness on Windermere.

697 McGinnis, M.D., Ostrom, E., 2014. Social-ecological system framework: Initial changes and continuing 698 challenges. Ecol. Soc. 19. https://doi.org/10.5751/ES-06387-190230

699 MEA, 2005. Millennium Ecosystem Assessment, Ecosystems and human well-being: Synthesis.

700 Metropolis, N., Ulam, S., 1949. The Monte Carlo Method. J. Am. Stat. Assoc. 44, 335-341.

$701 \quad$ https://doi.org/10.2307/2280232

702

703

704

705

706

707

708

709

710

711

712

713

714

715

716

717

718

719

720

721

722

723

724

725

726

727

728

729

730

731

732

733

734

735

736

737

738

Mouchet, M.A., Paracchini, M.L., Schulp, J., Stürck, J., Verkerk, P.J., Lavorel, S., Mouchet, M.A., Paracchini, M.L., Schulp, J., Stürck, J., Verkerk, P.J., 2017. Bundles of ecosystem ( dis ) services and multifunctionality across European landscapes. Ecol. Indic. 73, 23-28.

National Assembly for Wales, 2017. Summary report Branching out : a new ambition for woodland policies.

National Assembly for Wales, 2013. Forestry in Wales.

Natural Resources Wales, 2018. Terrestrial Phase 1 Habitat Survey [WWW Document]. URL http://le.gov.wales/catalogue/item/TerrestrialPhase1HabitatSurvey/?lang=en (accessed 9.21.18).

Ostrom, E., 2009. A general framework for analyzing sustainability of socio-ecologicl systems. Science (80-. ). 325, 419-423.

Pearce, D., Turner, R.K., 1990. Economics of Natural Resources and the Environment. Pearson, Harlow.

Pearce, D.W., 1993. Economic Values and the Natural World. MIT Press, Cambridge MA.

Population Reference Bureau, 2011. 2011 World Population Data Sheet. Washington DC.

Pretty, J.N., Brett, C., Gee, D., Hine, R.E., Mason, C.F., Morison, J.I.L., Raven, H., Rayment, M.D., Van Der Bijl, G., 2000. An assessment of the total external costs of UK agriculture. Agric. Syst. 65, 113-136. https://doi.org/10.1016/S0308-521X(00)00031-7

Reed, M.S., Bonn, A., Slee, W., Beharry-Borg, N., Birch, J., Brown, I., Burt, T.P., Chapman, D., Chapman, P.J., Clay, G.D., Cornell, S.J., Fraser, E.D.G., Glass, J.H., Holden, J., Hodgson, J.A., Hubacek, K., Irvine, B., Jin, N., Kirkby, M.J., Kunin, W.E., Moore, O., Moseley, D., Prell, C., Price, M.F., Quinn, C.H., Redpath, S., Reid, C., Stagl, S., Stringer, L.C., Termansen, M., Thorp, S., Towers, W., Worrall, F., 2009. The future of the uplands. Land use policy 26, 204-216.

https://doi.org/10.1016/j.landusepol.2009.09.013

Reis, S., Liska, T., Steinle, S., Carnell, E., Leaver, D., Roberts, E., Vieno, M., Beck, R., Dragosits, U., 2017. UK Gridded Population 2011 based on Census 2011 and Land Cover Map 2015.

Rodríguez, J.P., Beard, T.D., Bennett, E.M., Cumming, G.S., Cork, S.J., Agard, J., Dobson, A.P., Peterson, G.D., 2006. Trade-offs across space, time, and ecosystem services. Ecol. Soc. 11. https://doi.org/10.5751/ES-01667-110128

Saraev, V., MacCallum, S., Moseley, D., Valatin, G., 2017. Valuation of Welsh Forest Resources.

Scarpa, R., 2003. The recreation value of woodlands.

Schaubroeck, T., 2017. A need for equal consideration of ecosystem disservices and services when valuing nature; countering arguments against disservices. Ecosyst. Serv. 26, 95-97. https://doi.org/10.1016/j.ecoser.2017.06.009

Sen, A., Darnell, A., Crowe, A., Bateman, I.J., Munday, P., 2011. Economic Assessment of the Recreational Value of Ecosystems in Great Britain, Report to the Economics Team of the UK National Ecosystem Assessment.

Shackleton, C.M., Ruwanza, S., Sinasson Sanni, G.K., Bennett, S., De Lacy, P., Modipa, R., Mtati, N., Sachikonye, M., Thondhlana, G., 2016. Unpacking Pandora's Box: Understanding and Categorising 
Ecosystem Disservices for Environmental Management and Human Wellbeing. Ecosystems 19, 587-600. https://doi.org/10.1007/s10021-015-9952-z

741 Sivia, D.S., 1996. Data Analysis. A Bayesian Tutorial. Oxford Science Publication.

742 Spangenberg, J.H., Settele, J., 2016. Value pluralism and economic valuation - defendable if well done.

743 Ecosyst. Serv. 18, 100-109. https://doi.org/10.1016/j.ecoser.2016.02.008

744 Spangenberg, J.H., Settele, J., 2010. Precisely incorrect? Monetising the value of ecosystem services.

$745 \quad$ Ecol. Complex. 7, 327-337. https://doi.org/10.1016/j.ecocom.2010.04.007

746 UKCCC, 2017. Building a low-carbon economy in Wales. Setting Welsh carbon targets.

747 UKNEA, 2011. UK National Ecosystem Assessment: Technical Report. Cambridge.

748 Verhagen, W., Verburg, P.H., Schulp, N., Strürck, J., 2015. Mapping Ecosystem Services, in: Bouma, J.A., 749 Beukering, P.J.H. van (Eds.), Ecosystem Services: From Concept to Proactice. Cambridge University $750 \quad$ Press, Cambridge, pp. 65-87.

Wegner, G., Pascual, U., 2011. Cost-benefit analysis in the context of ecosystem services for human well-being: A multidisciplinary critique. Glob. Environ. Chang. 21, 492-504. https://doi.org/10.1016/j.gloenvcha.2010.12.008

754 Willis, K.G., 2002. Benefits and costs of forests to water supply and water quality.

755 Willis, K.G., Garrod, G., Scarpa, R., Lovett, A., Bateman, I.J., Hanley, N., Macmillan, D.C., Commission, F., 2003. The Social and Environmental Benefits of Forests in Great Britain. https://doi.org/10.1080/09640560600601587 